Article

\title{
Drying of Phyla nodiflora Leaves: Antioxidant Activity, Volatile and Phytosterol Content, Energy Consumption, and Quality Studies
}

\author{
Lisa Yen Wen Chua ${ }^{1}$, Bee Lin Chua ${ }^{1, *(\mathbb{D}}$, Adam Figiel ${ }^{2}{ }^{(D}$, Chien Hwa Chong ${ }^{3}{ }^{(}$, \\ Aneta Wojdyło ${ }^{4}\left(\mathbb{D}\right.$, Antoni Szumny ${ }^{5}(\mathbb{D})$ and Jacek Lyczko ${ }^{5}$ \\ 1 School of Engineering, Taylor's University, Lakeside Campus, No 1, Jalan Taylor's, Subang Jaya, \\ Selangor 47500, Malaysia; lisacyw92@gmail.com \\ 2 Institute of Agricultural Engineering, Wrocław University of Environmental and Life Sciences, \\ 37a Chełmońskiego Street, 51-630 Wrocław, Poland; adam.figiel@upwr.edu.pl \\ 3 School of Engineering and Physical Sciences, Heriot-Watt University Malaysia, No 1 Jalan Venna P5/2 \\ Precinct 5, Putrajaya 62200, Malaysia; chien_hwa.chong@hw.ac.uk \\ 4 Department of Fruit, Vegetable and Plant Nutraceuticals Technology, Wrocław University of Environmental \\ and Life Sciences, 371 Chełmońskiego Street, 51-630 Wrocław, Poland; aneta.wojdylo@upwr.edu.pl \\ 5 Department of Chemistry, Wrocław University of Environmental and Life Sciences, Norwida 25, \\ 53-375 Wrocław, Poland; antoni.szumny@upwr.edu.pl (A.S.); jacek.lyczko@upwr.edu.pl (J.Ł.) \\ * Correspondence: beelin.chua@taylors.edu.my; Tel.: +60-173099682
}

Received: 12 March 2019; Accepted: 10 April 2019; Published: 12 April 2019

\begin{abstract}
Drying is an important process in the preservation of antioxidants in medicinal plants. In this study, leaves of Phyla nodiflora, or commonly known as frog fruit, were dried using convective drying (CD) at 40,50 , and $60^{\circ} \mathrm{C}$; vacuum-microwave drying (VMD) at 6,9 , and $12 \mathrm{~W} / \mathrm{g}$; and convective pre-drying followed by vacuum-microwave finish drying (CPD-VMFD) at $50{ }^{\circ} \mathrm{C}$ and $9 \mathrm{~W} / \mathrm{g}$. Drying kinetics of $P$. nodiflora leaves was modelled, and the influences of drying methods on the antioxidant activity, total phenolic content, volatile and phytosterol contents, energy consumption, water activity, and color properties were determined. Results showed that drying kinetics was best described by modified Page model. VMD achieved highest drying rate, whereas VMFD considerably reduced the drying time of $\mathrm{CD}$ from $240 \mathrm{~min}$ to $105 \mathrm{~min}$. CPD-VMFD was the best option to dry $P$. nodiflora in terms of retaining volatiles and phytosterols, with lower energy consumption than CD. Meanwhile, VMD at $6 \mathrm{~W} / \mathrm{g}$ produced samples with the highest antioxidant activity with 2,2'-Azinobis (3-ethylbenzthiazoline-6-sulfonic acid) (ABTS) and ferric reducing antioxidant power (FRAP) value of 11.00 and $15.99 \mu \mathrm{M}$ Trolox/100 $\mathrm{g} \mathrm{dw}$, respectively.
\end{abstract}

Keywords: Phyla nodiflora; vacuum-microwaves; antioxidant activity; essential oil volatile composition; phytosterol; drying technology

\section{Introduction}

Antioxidants play important roles in nutrition by increasing the shelf life and preserving the nutritional aspect of lipid-containing food products. Antioxidants also prevent the oxidation of biological molecules in the body by chelating redox metals or quenching free radicals [1,2]. Plants contain numerous natural antioxidants and can be a source of new antioxidant compounds given the various chemical structures and mechanisms of action of these natural antioxidants [3]. Phyla nodiflora (L.) Greene, also known as Lippia nodiflora and widely known as frog fruit, belongs to family Verbenaceae and is distributed in subtropical and tropical regions [4,5]. Previous studies have confirmed the presence of antioxidants in P. nodiflora extracts [6,7], namely, stigmasterols, nodifloretin, nodiflorin, 
lippiflorin, and batalilfolin [4]. Traditionally, the leaves are used to treat diarrhea, fever, cold, knee joints pain, and gonorrhea [5]. Fresh leaves are high in moisture and are perishable commodities [8]. The antioxidant compounds in the leaves may undergo reduction during the period between harvesting and processing. Thus, fresh medicinal plants must be effectively preserved by removing moisture to inactivate enzymatic, chemical and metabolic reactions, which may otherwise cause the loss of important antioxidants [9].

Moisture removal from food is an integral operation in food processing. Convective drying (CD) has remained the most common drying method to reduce moisture from food and biomaterials. In CD, heat is transferred convectively from the hot air or combustion gasses to the cooler moist boundaries of the drying material. Thereafter, heat diffuses into the drying material primarily through conduction. Evaporation of moisture at the surface of the material is efficient; however, the removal of moisture from the center regions to the surface is slow because it is driven by a moisture concentration gradient, rendering $\mathrm{CD}$ a low drying rate method [10]. In view of the limitations of $\mathrm{CD}$, there is increasing interest in emerging drying technologies, such as microwave drying, which gives better drying performance. Microwave drying is gaining popularity because drying time can be reduced and a higher retention of active constituents can be achieved. Despite fast drying rates, the heterogenic structure of materials and the inhomogeneity of microwave field may result in hot spots within the material at the final stage of drying [11]. A solution is to use microwave drying in combination with vacuum drying. This combination has been proven effective in many previous studies on preserving active compounds in the drying of herbs and fruits [12,13]. Furthermore, a lower pressure of vacuum-microwave drying (VMD) induces quicker water evaporation from food material at a lower temperature [14], thereby reducing chemical alterations [15]. However, high water evaporation from plant material at the initial stage of VMD can exceed the vacuum pump's capacity, so reducing the material load or a larger vacuum pump installation is required $[11,14]$. Pre-drying through $C D$, hereafter denoted as $\mathrm{CPD}$, reduces the load mass of raw material to be dried in VMD. This two-stage drying method of CPD followed by vacuum-microwave finish drying (VMFD), hereafter denoted as CPD-VMFD, reduces the total cost of dehydration and improves the quality of products [16].

Although the chemical composition of several herb species dried using vacuum-microwaves has already been well recognized $[13,17,18]$, to date no studies have investigated the influences of VMD and CPD-VMFD on the antioxidant activity of P. nodiflora and similar species. Therefore, it is of interest to evaluate the effectiveness of new vacuum-microwave drying methods compared to conventional CD in retaining bioactive constituents. In the present work, the drying kinetics and energy consumption of $\mathrm{CD}, \mathrm{VMD}$, and CPD-VMFD were determined, and the influence of all investigated drying methods was evaluated in terms of antioxidant activity, total phenolic content, concentration of volatiles and phytosterols, color properties, and water activity. Fatty acids were also profiled to identify active constituents in the plant extracts.

\section{Results and Discussion}

\subsection{Drying Kinetics}

Figure 1a shows the drying kinetics of P. nodiflora leaves dried with CD and CPD-VMFD, while Figure $1 \mathrm{~b}$ shows the drying kinetics of $P$. nodiflora dried using VMD. Drying kinetics of all drying methods were best described by an exponential function, namely, the modified Page model (Equation (4)). Table 1 shows the values of both statistical parameters and mathematical constants of the Lewis, modified Page and Henderson and Pabis model. Selection of the best model was based on the highest Coefficient of determination $\left(R^{2}\right)$ and the lowest root-mean-square error (RMSE), thereby suggesting goodness of fit. The values, $R^{2}$ and RMSE, obtained suggest a good agreement between the experimental values obtained and the modified Page model. 


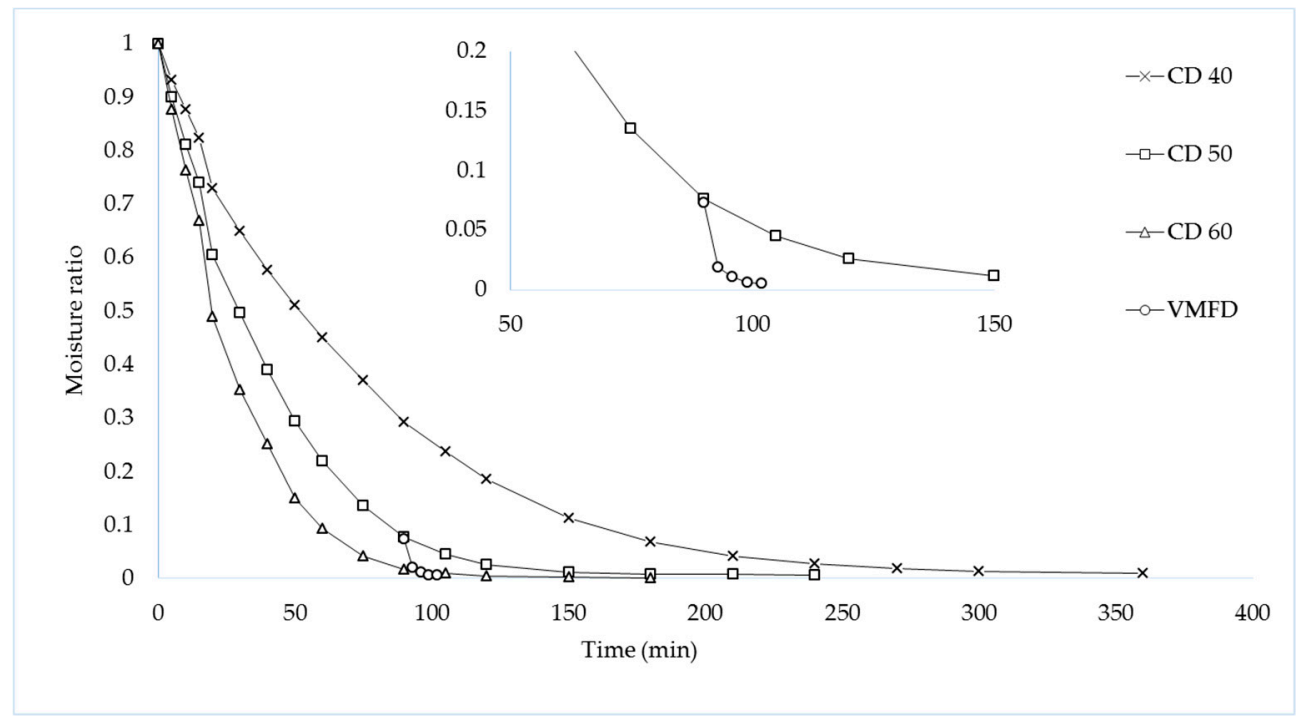

(a)

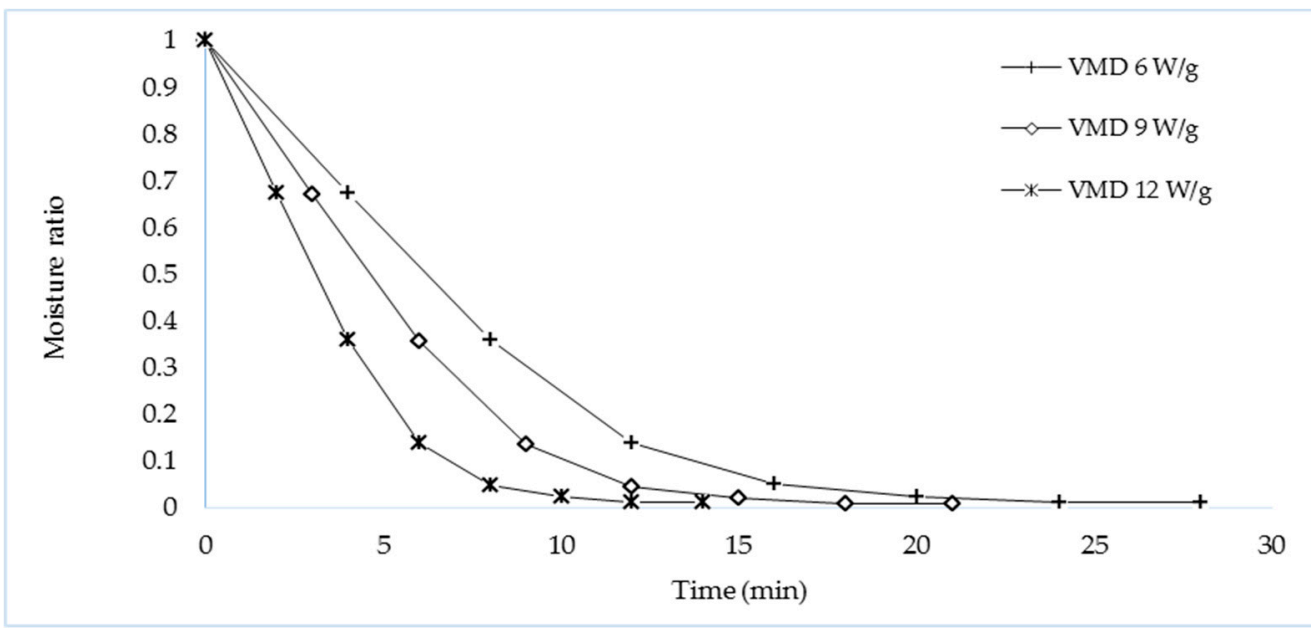

(b)

Figure 1. (a) Drying kinetics of Phyla nodiflora leaves dried using convective drying (CD) method at 40,50 , and $60^{\circ} \mathrm{C}$ and vacuum microwave finish drying (VMFD) at $9 \mathrm{~W} / \mathrm{g}$ preceded by convective predrying $(\mathrm{CPD})$ at $50{ }^{\circ} \mathrm{C}$. (b) Drying kinetics of $P$. nodiflora leaves dried using vacuum microwave drying (VMD) at 6,9 , and $12 \mathrm{~W} / \mathrm{g}$. 
Table 1. Statistical parameters, total drying duration, and mathematical model constants describing the drying kinetics of $P$. nodiflora leaves.

\begin{tabular}{|c|c|c|c|c|c|c|c|}
\hline Drying Condition & Model & $a$ & $k$ & $n$ & $R^{2}$ & RMSE & Drying Time (min) \\
\hline \multirow{3}{*}{$\mathrm{CD} 40^{\circ} \mathrm{C}$} & Lewis & - & 0.0138 & - & 0.9989 & 0.0113 & \multirow{3}{*}{360} \\
\hline & Page (modified) & 0.9937 & 0.0126 & 1.0209 & 0.9989 & 0.0117 & \\
\hline & Henderson-Pabis & 1.0000 & 0.0138 & - & 0.9989 & 0.0117 & \\
\hline \multirow{3}{*}{$\mathrm{CD} 50^{\circ} \mathrm{C}$} & Lewis & - & 0.0246 & - & 0.9962 & 0.0216 & \multirow{3}{*}{240} \\
\hline & Page (modified) & 0.9943 & 0.0151 & 1.1293 & 0.9989 & 0.0124 & \\
\hline & Henderson-Pabis & 1.0284 & 0.0254 & - & 0.9972 & 0.0193 & \\
\hline \multirow{3}{*}{$\mathrm{CD} 60^{\circ} \mathrm{C}$} & Lewis & - & 0.0287 & - & 0.9778 & 0.0493 & \multirow{3}{*}{180} \\
\hline & Page (modified) & 1.0324 & 0.0371 & 0.9376 & 0.9788 & 0.0521 & \\
\hline & Henderson-Pabis & 1.0168 & 0.0293 & - & 0.9782 & 0.0507 & \\
\hline \multirow{3}{*}{ VMD $6 \mathrm{~W} / \mathrm{g}$} & Lewis & - & 0.1860 & - & 0.9794 & 0.0534 & \multirow{3}{*}{21} \\
\hline & Page (modified) & 0.9983 & 0.0766 & 1.4702 & 0.9996 & 0.0086 & \\
\hline & Henderson-Pabis & 1.0402 & 0.1919 & - & 0.9813 & 0.0549 & \\
\hline \multirow{3}{*}{ VMD $9 \mathrm{~W} / \mathrm{g}$} & Lewis & - & 0.1860 & - & 0.9794 & 0.0534 & \multirow{3}{*}{21} \\
\hline & Page (modified) & 0.9983 & 0.0766 & 1.4702 & 0.9996 & 0.0086 & \\
\hline & Henderson-Pabis & 1.0402 & 0.1919 & - & 0.9813 & 0.0549 & \\
\hline \multirow{3}{*}{ VMD 12 W/g } & Lewis & - & 0.2769 & - & 0.9801 & 0.0523 & \multirow{3}{*}{14} \\
\hline & Page (modified) & 0.9986 & 0.1403 & 1.4582 & 0.9996 & 0.0091 & \\
\hline & Henderson-Pabis & 0.9986 & 0.1403 & - & 0.9996 & 0.0091 & \\
\hline \multirow{3}{*}{$\begin{array}{c}\text { CPD-VMFD } 50^{\circ} \mathrm{C}, 9 \\
\mathrm{~W} / \mathrm{g}\end{array}$} & Lewis & - & 0.0754 & - & 0.9811 & 0.0521 & \multirow{3}{*}{105} \\
\hline & Page (modified) & 0.0733 & 0.7681 & 0.5011 & 0.9997 & 0.0007 & \\
\hline & Henderson-Pabis & 0.0725 & 0.3734 & - & 0.9782 & 0.0049 & \\
\hline
\end{tabular}

Drying duration of $C D$ was the longest compared with VMD and CPD-VMFD. At the initial stage of $C D$, moisture loss was fast; however, successive moisture loss reduced with time. This phenomenon occurs because $\mathrm{CD}$ uses surface heating; the evaporation of moisture from the surface of plant material was efficient but moisture diffusion from internal region to the surface is slow and rate-limiting [19]. However, when VMFD at $9 \mathrm{~W} / \mathrm{g}$ was applied to convective pre-dried leaves, drying time was $105 \mathrm{~min}$, as opposed to $240 \mathrm{~min}$ of $\mathrm{CD}$, thereby achieving 2.3 times shorter drying duration.

The relationship between drying rate and moisture ratio is shown in Figure 2. The drying rate of VMD was the highest, which was attributed to the volumetric heating of microwave drying. Microwaves penetrate inner regions of leaf tissue, thereby producing heat by the absorption of microwave energy by water molecules. Increased positive steam pressure in leaf structure pushes vapor to the surface to be removed [20]. CD recorded the lowest drying rates, but these values increased with increased temperatures. An increase from 40 to $50{ }^{\circ} \mathrm{C}$ showed an average increase of $0.003 \mathrm{~min}^{-1}$, whereas in the case of VMD, an increase from 6 to $9 \mathrm{~W} / \mathrm{g}$ showed a higher average drying rate of $0.012 \mathrm{~min}^{-1}$. The low drying rate of $\mathrm{CD}$ at $50^{\circ} \mathrm{C}$ can be compensated for by the introduction of VMFD, which showed a considerable improvement in drying rate at low moisture ratios. 


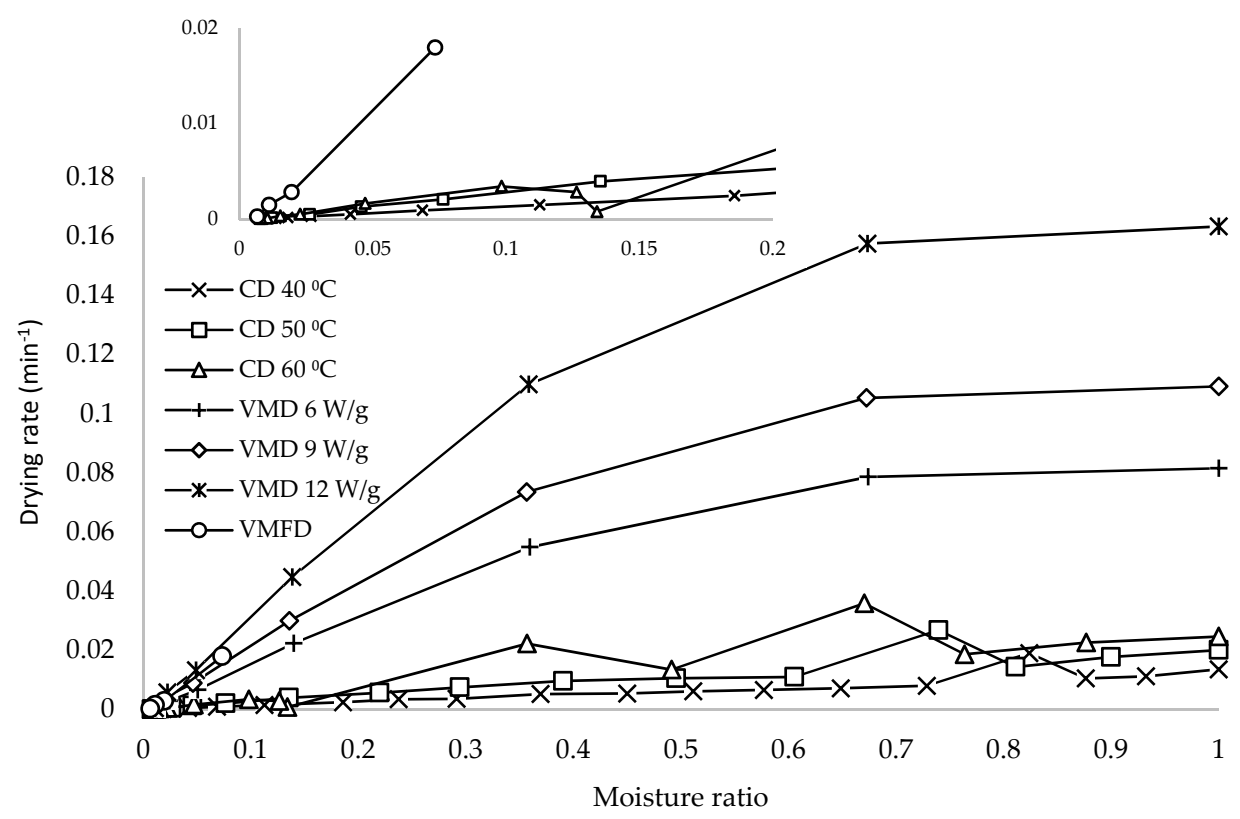

Figure 2. Drying rate for $P$. nodiflora leaves dehydrated using $C D$ method at 40,50 , and $60{ }^{\circ} \mathrm{C}, \mathrm{VMD}$ at 6,9 , and $12 \mathrm{~W} / \mathrm{g}$, and VMFD at $9 \mathrm{~W} / \mathrm{g}$ preceded by $\mathrm{CPD}$ at $50^{\circ} \mathrm{C}$.

The drying rate also decreased with decreased moisture ratio. This falling rate period is characterized by a continuous decrease in drying rate [17]. With VMD, a higher drying rate is typically observed at the initial stage as moisture content was initially higher in leaves, and this finding corresponded to a higher dielectric constant. Larger microwave radiation was absorbed by the sample, generating more heat, thereby increasing the drying rate. As drying progressed, the reduced amount of moisture reduced the microwave absorption, resulting in decreased drying rates.

\subsection{Specific Energy Consumption}

Profiles of specific energy consumptions are shown in Figures 3 and 4. Curve shapes revealed that as moisture content decreases, specific energy consumption increased, with a drastic increment at the final stage of drying, as characterized by the critical moisture content, $K$. The $K$ values of all drying methods (below $0.1847 \mathrm{~kg}$ water $\mathrm{kg}^{-1} \mathrm{dw}$ ) are indicated in Figures 3 and 4 . The shape of characteristic curves resulted from the course of the drying kinetics shown in Figure 1a,b. The shape of the drying curves in Figure $1 \mathrm{a}, \mathrm{b}$ shows that moisture removal was time consuming when moisture content was low. The prolonged time period to remove moisture at the final stages of drying corresponded to the high energy requirement for the removal of the same amount of moisture at the final stage of drying compared to initial drying stages. This behavior is usually seen in plant materials with osmotic cellular structure to limit the escape of moisture from plant tissues [21]. 


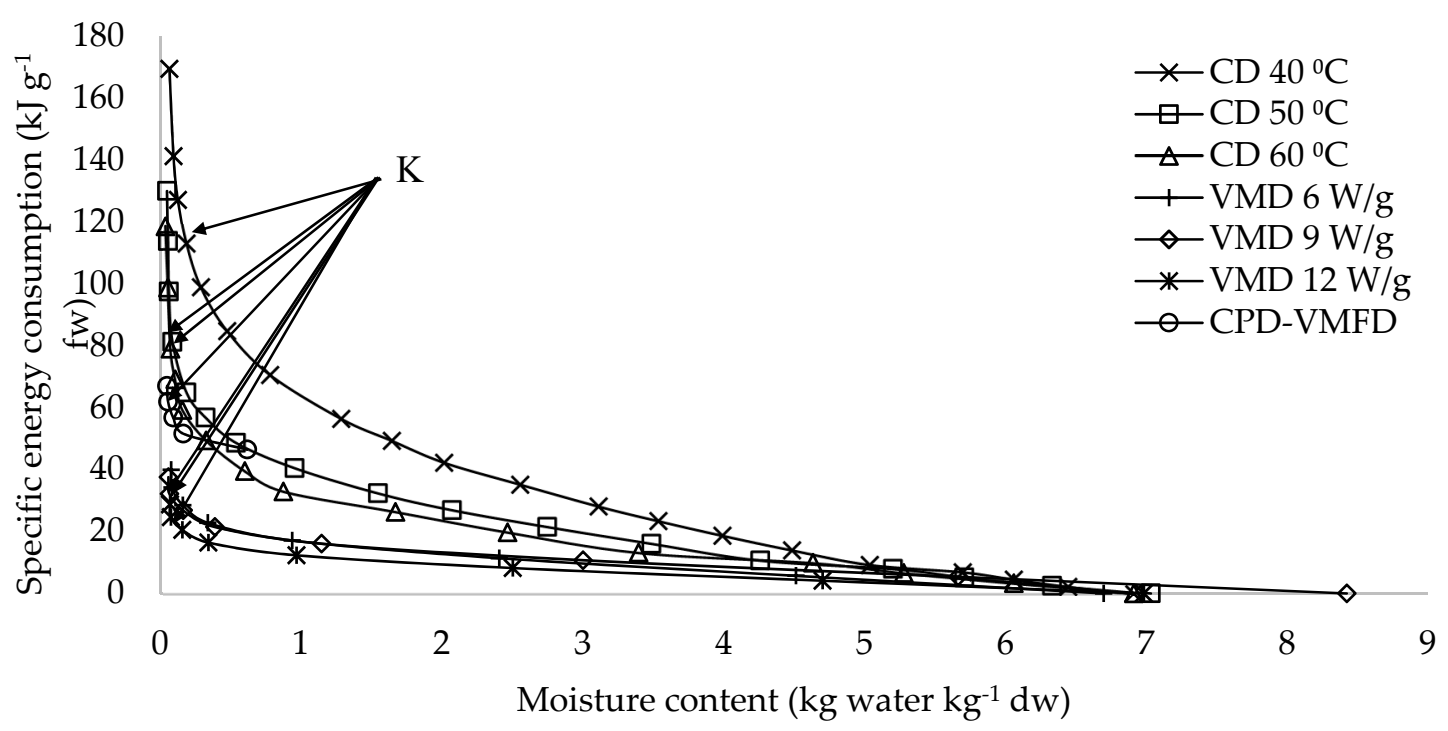

Figure 3. Profile of specific energy consumption for drying a gram of $P$. nodiflora leaves, dried using CD, VMD, and CPD-VMFD methods.

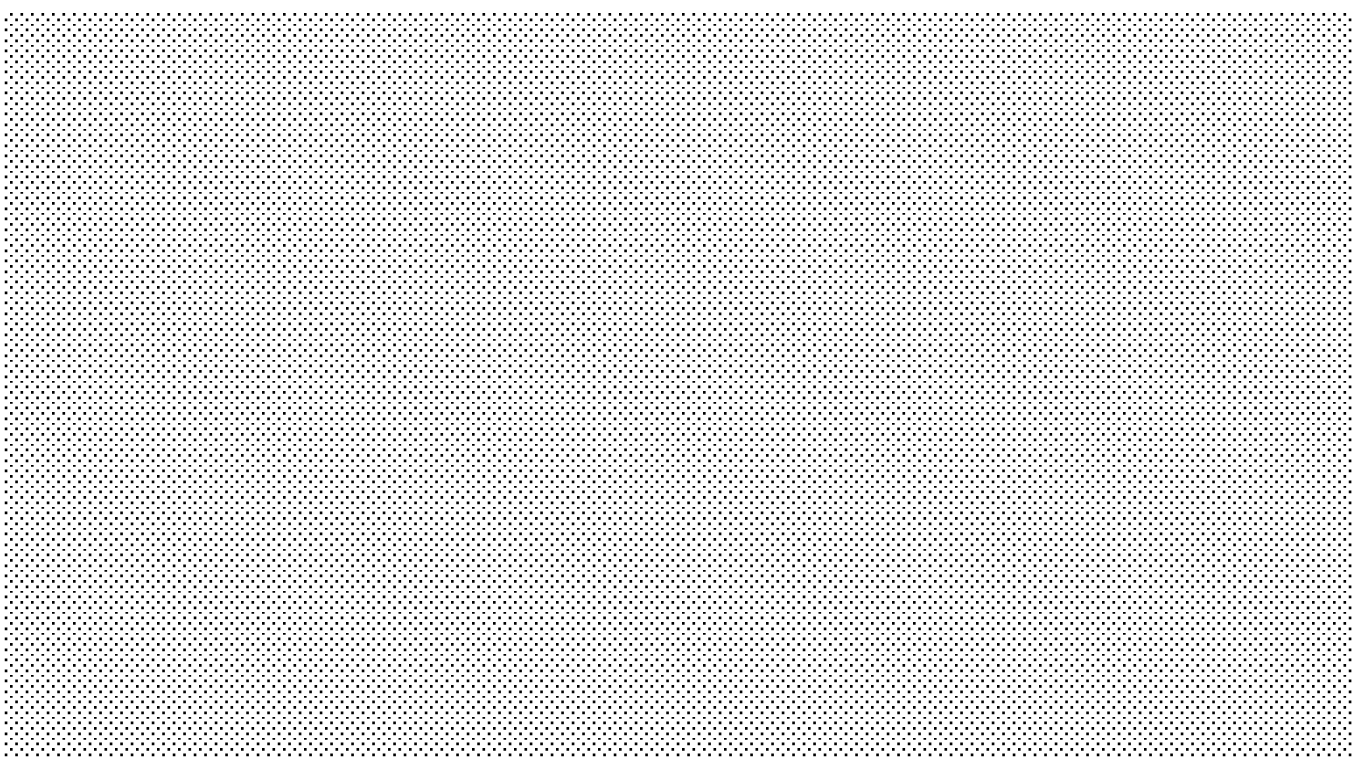

Figure 4. Profile of specific energy consumption related to the gram of water evaporated from sample of $P$. nodiflora leaves, dried using CD, VMD, and CPD-VMFD methods.

VMD required less energy to remove moisture compared with CD. However, energy consumption of CD can be minimized with VMFD, reducing final specific energy consumptions of CD by $80.2 \%$ and $51.1 \%(\mathrm{~kJ} / \mathrm{g}$ water). CPD reduced water load by $92.4 \%$, from an initial moisture content of 7.032 to $0.537 \mathrm{~kg}$ water $\mathrm{kg}^{-1} \mathrm{dw}$. Drying intensity was also an influencing factor on the respective specific energy consumptions. Higher drying intensities in terms of increased hot-air temperature and microwave wattage reduced final specific energy consumptions (Figure 5), which is consistent with observations of past reports [21,22]. 


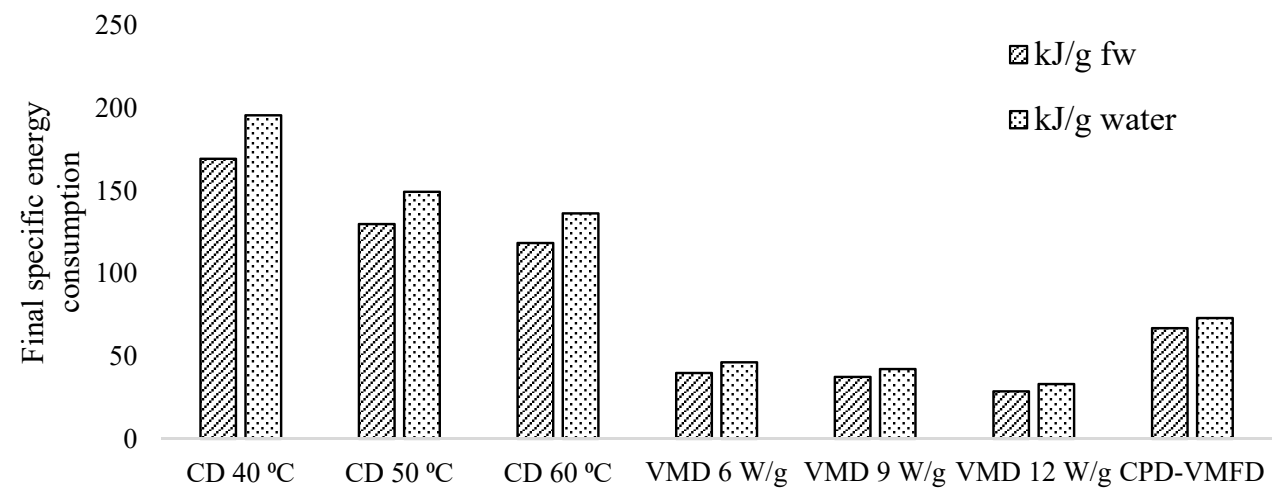

Figure 5. Final specific energy consumptions of CD, VMD, and CPD-VMFD of $P$. nodiflora leaves.

\subsection{Antioxidant Activity and Total Phenolic Content Analysis}

Analysis of antioxidant activity showed that the highest antioxidant activity was observed for VMD $6 \mathrm{~W} / \mathrm{g}$ samples 2,2'-Azinobis (3-ethylbenzthiazoline-6-sulfonic acid (ABTS), $11.00 \mu \mathrm{M}$ Trolox/100 g dw; ferric reducing antioxidant power (FRAP), $15.99 \mu \mathrm{M}$ Trolox/100 $\mathrm{g} \mathrm{dw}$ ). The lowest antioxidant activity was obtained with VMD $12 \mathrm{~W} / \mathrm{g}$ with an ABTS value of $6.62 \mu \mathrm{M}$ Trolox/100 $\mathrm{g} \mathrm{dw}$, whereas the lowest FRAP value of $8.26 \mu \mathrm{M}$ Trolox/100 $\mathrm{g} d w$ was shown by $\mathrm{CD} 40^{\circ} \mathrm{C}$ samples (Table 2).

Table 2. Effects of drying methods on the antioxidant activity and total phenolic content of P. nodiflora leaves.

\begin{tabular}{|c|c|c|c|}
\hline \multirow{2}{*}{ Drying Method } & \multicolumn{2}{|c|}{ Antioxidant Activity ( $\mu \mathrm{M}$ Trolox/100 g dw) } & \multirow{2}{*}{$\begin{array}{l}\text { Total Phenolic Content } \\
\text { (mg/100 g dw) }\end{array}$} \\
\hline & ABTS & FRAP & \\
\hline Fresh & $14.34 \pm 0.93^{b}$ & $18.25 \pm 0.54^{b}$ & $1484.46 \pm 30.68^{a}$ \\
\hline $\mathrm{CD} 40^{\circ} \mathrm{C}$ & $7.60 \pm 0.46^{\mathrm{a}, \mathrm{d}}$ & $8.26 \pm 0.54^{\mathrm{a}, \mathrm{c}}$ & $1609.73 \pm 69.24^{\mathrm{a}, \mathrm{c}}$ \\
\hline $\mathrm{CD} 50^{\circ} \mathrm{C}$ & $10.25 \pm 0.77^{c, d}$ & $14.18 \pm 1.69 \mathrm{e}, \mathrm{f}$ & $1762.20 \pm 31.38^{a, c}$ \\
\hline $\mathrm{CD} 60^{\circ} \mathrm{C}$ & $10.54 \pm 1.22^{c}$ & $14.17 \pm 0.91 \mathrm{e}, \mathrm{f}$ & $1828.92 \pm 110.18^{c}$ \\
\hline VMD $6 \mathrm{~W} / \mathrm{g}$ & $11.00 \pm 0.19^{c}$ & $15.99 \pm 1.53^{\mathrm{b}, \mathrm{f}}$ & $1661.54 \pm 123.30^{\mathrm{a}, \mathrm{c}}$ \\
\hline VMD $9 \mathrm{~W} / \mathrm{g}$ & $9.28 \pm 0.34^{\mathrm{a}, \mathrm{c}, \mathrm{d}}$ & $10.21 \pm 0.16^{\mathrm{c}, \mathrm{d}}$ & $1091.26 \pm 136.04^{b}$ \\
\hline VMD $12 \mathrm{~W} / \mathrm{g}$ & $6.62 \pm 0.633^{a}$ & $9.25 \pm 1.31^{\mathrm{c}, \mathrm{d}}$ & $1473.23 \pm 80.60^{a}$ \\
\hline CPD-VMFD & $7.11 \pm 2.15^{\mathrm{a}}$ & $12.11 \pm 0.50^{\mathrm{d}, \mathrm{e}}$ & $2352.93 \pm 101.09^{d}$ \\
\hline
\end{tabular}

ABTS-2,2'-Azinobis (3-ethylbenzthiazoline-6-sulfonic acid); FRAP-ferric reducing antioxidant capacity; VMD—vacuum microwave drying; CPD—convective pre-drying; VMFD—vacuum microwave finish drying; mean values with different alphabets $(\mathrm{a}, \mathrm{b}, \mathrm{c}, \mathrm{d})$ within each column is significantly different $(p<0.05)$, according to Tukey's test.

Active compounds of thermally dried herbs were assumed to have undergone thermal degradation and oxidative degradation in the case of CD and CPD-VMFD, thereby leading to the lower antioxidant activities observed. The results clearly indicate that a suitable application of hot-air temperature and microwave power, during $\mathrm{CD}$ and VMD, have the potential in yielding high antioxidant activities. A low microwave power of $6 \mathrm{~W} / \mathrm{g}(\mathrm{VMD})$ and a higher temperature of $60^{\circ} \mathrm{C}$ in $\mathrm{CD}$ were beneficial in yielding high antioxidant activities.

The intensity of drying treatment also affected antioxidant activity. The increase in temperature of $\mathrm{CD}$, from 40 to $60^{\circ} \mathrm{C}$, shortened the drying length within 360 to $180 \mathrm{~min}$. At 50 and $60^{\circ} \mathrm{C}$, the degradation of heat-sensitive compounds was considerably lower compared to $\mathrm{CD}$ at $40{ }^{\circ} \mathrm{C}$, which was confirmed by relatively high antioxidant activity. These results indicate that the increase in temperature during $\mathrm{CD}$ is effective in accelerating the drying process, thereby shortening sample's exposure to elevated drying temperature in a highly oxygenated condition. With increased microwave power of VMD, from 6 to $12 \mathrm{~W} / \mathrm{g}$, antioxidant activity decreased. The increase in microwave power from 6 to $12 \mathrm{~W} / \mathrm{g}$ decreased the drying time from 28 to $21 \mathrm{~min}$, which; however, did not contribute to the preservation of antioxidant activity in the same way as observed in the case of CD. Evidently, the reduction in drying 
time did not compensate for the degradation of the antioxidant compounds resulting from the greater amount of heat generated inside the material by increased microwave radiation.

The lengthy CD process can be shortened with microwave heating, as seen in CPD-VMFD. Results of FRAP assay showed that CPD-VMFD produced samples of higher or not significantly different antioxidant activity from samples dried exclusively with CD or VMD. The higher antioxidant activity of CPD-VMFD samples compared to $\mathrm{CD}$ at $40^{\circ} \mathrm{C}$ (for FRAP assay) can be explained by the shortened drying time of the former. The presence of high moisture, oxygen, and heat during the lengthy drying process of $\mathrm{CD} 40^{\circ} \mathrm{C}$ may have facilitated the degradation of antioxidant compounds by enzymes [23]. As for the higher antioxidant activity of CPD-VMFD samples compared with VMD at 9 and $12 \mathrm{~W} / \mathrm{g}$, the oxygen exposure during CPD-VMFD did not cause a large reduction in antioxidant activity. Several previous studies have indicated that phenolic content and antioxidant activity increase after heat treatment of peppermint leaves, Artemisia annua leaves [24], and culinary herbs, namely basil, rosemary, oregano, sage, thyme, and marjoram [25]. Wojdylo et al. suggested that polyphenols found in strawberry fruits that were exposed to oxygenated condition may have high antioxidant activity, although the increase is temporary [26].

Unexpectedly, the total phenolic content (TPC) values of fresh samples were lower than those of dried samples. The thermal treatment may have promoted an easier release of cell constituents from plant cells [27], as heat exerts modifications to plant tissue microstructure, thereby reducing cell integrity [28] and allowing for the easy exit of phenolic compounds from plant cells. Dried leaves have the tendency to exhibit increased bioactivity, as reported in past studies [29,30]. Moisture loss in leaves during drying, an abiotic stress, may have triggered the production and accumulation of phenolic compounds, thereby increasing the overall antioxidant activity [31]. Furthermore, the increase in antioxidant activity may have resulted from the Maillard reaction and the formation of Maillard reaction products (MRPs) with antioxidant power [26].

Although the TPC of samples dried with CPD-VMFD was high, antioxidant activity was relatively low. This finding implies that TPC of P. nodiflora did not correlate with the antioxidant activity. There are three major classes of chemical compounds in plants: phenolic metabolites, alkaloids, and terpenoids [32]. Phenolic compounds are the most researched and regarded as potent antioxidants; thus, the correlation between TPC and antioxidant activity has often been made. Terpenoids have also been established to exhibit strong antioxidant properties [33]. Therefore, in the case of P. nodiflora, it was assumed that terpenes and terpenoids present, which accounted for $36.5 \%$ of total volatiles, may have contributed to the overall antioxidant activity.

The overall antioxidant activity of $P$. nodiflora may be contributed by the major constituents in the extract and essential oil. For instance, 1-octen-3-ol, the major volatile compound (Table 3), $\beta$-sitosterol (Table 4 ) and $\alpha$-linolenic acid, accounting for $48.3 \%$ of total fatty acids (Table 5 ), are among the antioxidants considered potent [34]. Terpenoids are known to exert antioxidant effect because of their ability to interact with free radicals. The presence of various terpenoids in the volatile fraction of $P$. nodiflora could also contribute to the antioxidant effect. With the presence of a wide variety of constituents in the extract of $P$. nodiflora, it can be assumed that the synergistic interactions between these molecules have effectively led to the observed antioxidant activities.

\subsection{Analysis of Volatile Contents}

Eighty-three compounds were identified in P. nodiflora leaves, amounting to $176.81 \mathrm{mg}^{100 \mathrm{~g}^{-1} \mathrm{db}}$ of volatile compounds in fresh leaves (Table 3). Figure 6 shows a typical chromatogram of the volatile compounds identified. The major volatiles present in fresh $P$. nodilfora were 1-octen-3-ol (60.34 mg $\left.100 \mathrm{~g}^{-1} \mathrm{db}\right)$, 2-hexenal (20.42 mg $\left.100 \mathrm{~g}^{-1} \mathrm{db}\right)$, and $\alpha$-amorphene (10.55 mg $100 \mathrm{~g}^{-1} \mathrm{db}$ ). The volatiles present in $P$. nodilfora can be are categorized under the following groups; alcohols ( $42.5 \%)$, sesquiterpenes $(21.8 \%)$, aldehydes $(16.2 \%)$, sesquiterpenoids $(8.4 \%)$, monoterpenoids $(3.2 \%)$, esters $(3.0 \%)$, monoterpenes $(2.5 \%)$ and diterpenoids $(0.6 \%)$, thereby representing $98.2 \%$ of total volatiles. Other volatile compounds, phenylpropenes and ketones, were present in small concentrations. 
Table 3. Concentration of volatile compounds influenced by various drying methods and conditions.

\begin{tabular}{|c|c|c|c|c|c|c|c|c|c|c|c|}
\hline \multirow{3}{*}{ Compound } & \multirow{3}{*}{ RT } & \multirow{2}{*}{\multicolumn{2}{|c|}{ Retention Indexes }} & \multirow{2}{*}{ Fresh } & \multirow{2}{*}{ CPD-VMFD } & \multicolumn{3}{|c|}{ CD } & \multicolumn{3}{|c|}{ VMD } \\
\hline & & & & & & $40^{\circ} \mathrm{C}$ & $50{ }^{\circ} \mathrm{C}$ & $60^{\circ} \mathrm{C}$ & $6 \mathrm{~W} / \mathrm{g}$ & $9 \mathrm{~W} / \mathrm{g}$ & $12 \mathrm{~W} / \mathrm{g}$ \\
\hline & & Exp. & Lit. & \multicolumn{8}{|c|}{ Concentration $\left(\mathrm{mg} 100 \mathrm{~g}^{-1} \mathrm{db}\right)$} \\
\hline 2-Hexenal & 4.756 & 843 & 851 & 20.42 & 6.49 & 1.41 & 3.36 & 0.88 & 0.05 & 0.42 & 0.09 \\
\hline (E)-2-Hexen-1-ol & 5.034 & 858 & 862 & 0.54 & 0.45 & 0.08 & 0.41 & 0.09 & 0.00 & 0.00 & 0.00 \\
\hline 1-Hexanol & 5.077 & 861 & 868 & 0.57 & 3.09 & 0.77 & 0.97 & 0.36 & 0.02 & 0.04 & 0.04 \\
\hline 2-Heptanol & 5.818 & 899 & 901 & 0.00 & 0.98 & 0.00 & 0.24 & 0.10 & 0.05 & 0.25 & 0.09 \\
\hline$(\mathrm{E}, \mathrm{E})-2,4$-Hexadienal & 6.083 & 909 & 911 & 0.93 & 0.51 & 0.15 & 0.40 & 0.11 & 0.00 & 0.00 & 0.06 \\
\hline Benzaldehyde & 7.497 & 959 & 962 & 1.38 & 2.24 & 0.56 & 0.83 & 0.70 & 0.20 & 0.87 & 0.56 \\
\hline 1-Octen-3-ol & 8.099 & 883 & 880 & 60.34 & 79.06 & 19.30 & 21.84 & 21.11 & 1.89 & 8.80 & 6.03 \\
\hline 6-Methyl-5-hepten-2-one & 8.265 & 986 & 986 & 1.15 & 2.35 & 0.83 & 0.79 & 0.40 & 0.07 & 0.58 & 0.30 \\
\hline 3-Octanol & 8.444 & 992 & 994 & 0.64 & 0.33 & 0.04 & 0.03 & 0.06 & 0.01 & 0.22 & 0.05 \\
\hline 6-Methyl-5-hepten-2-ol & 8.528 & 997 & 994 & 3.49 & 5.19 & 1.66 & 2.22 & 1.50 & 0.10 & 0.90 & 0.36 \\
\hline Octanal & 8.761 & 1002 & 1003 & 0.23 & 0.23 & 0.03 & 0.05 & 0.02 & 0.11 & 0.35 & 0.05 \\
\hline (E,E)-2,4-Heptadienal & 9.012 & 1011 & 1012 & 0.22 & 3.93 & 0.38 & 1.42 & 0.93 & 0.16 & 1.36 & 0.69 \\
\hline (E,E)-2,4-Heptadienol & 9.223 & 1015 & - & 0.91 & 0.02 & 0.03 & 0.05 & 0.01 & 0.00 & 0.01 & 0.00 \\
\hline p-Cymene & 9.474 & 1024 & 1025 & 0.36 & 0.27 & 0.42 & 0.12 & 0.01 & 0.04 & 0.15 & 0.11 \\
\hline Limonene & 9.610 & 1029 & 1030 & 0.35 & 0.10 & 0.13 & 0.20 & 0.00 & 0.02 & 0.47 & 0.14 \\
\hline Eucalyptol & 9.700 & 1031 & 1032 & 0.01 & 0.00 & 0.00 & 0.00 & 0.00 & 0.00 & 0.02 & 0.00 \\
\hline Benzyl alcohol & 9.893 & 1035 & 1036 & 1.01 & 1.07 & 0.12 & 0.04 & 0.24 & 0.04 & 0.25 & 0.02 \\
\hline$\beta$-Ocimene & 9.893 & 1038 & 1037 & 0.12 & 0.34 & 0.03 & 0.06 & 0.09 & 0.01 & 0.04 & 0.01 \\
\hline Benzeneacetaldehyde & 10.076 & 1042 & 1045 & 2.96 & 1.70 & 0.51 & 0.55 & 0.63 & 0.37 & 1.39 & 0.72 \\
\hline$\gamma$-Terpinene & 10.563 & 1059 & 1060 & 0.49 & 0.15 & 0.04 & 0.16 & 0.03 & 0.00 & 0.02 & 0.11 \\
\hline cis-Sabinene hydrate & 10.884 & 1068 & 1070 & 0.04 & 0.03 & 0.00 & 0.03 & 0.00 & 0.00 & 0.00 & 0.03 \\
\hline cis-Linalool oxide & 11.065 & 1072 & 1074 & 2.33 & 6.46 & 0.90 & 2.41 & 1.94 & 0.21 & 1.40 & 0.00 \\
\hline Fenchone & 11.584 & 1088 & 1096 & 0.02 & 0.00 & 0.02 & 0.00 & 0.01 & 0.00 & 0.02 & 0.67 \\
\hline 2-Nonanone & 11.669 & 1091 & 1092 & 0.00 & 0.20 & 0.12 & 0.54 & 0.56 & 0.00 & 0.10 & 0.00 \\
\hline Linalool & 11.961 & 1100 & 1099 & 0.23 & 0.06 & 0.12 & 0.13 & 0.10 & 0.02 & 0.08 & 0.01 \\
\hline Nonanal & 12.086 & 1104 & 1104 & 0.86 & 0.40 & 0.04 & 0.33 & 0.23 & 0.08 & 0.37 & 0.05 \\
\hline$\beta$-Thujone & 12.184 & 1107 & 1114 & 0.05 & 4.09 & 0.13 & 0.81 & 1.22 & 0.15 & 1.56 & 0.22 \\
\hline Phenylethyl Alcohol & 12.422 & 1114 & 1116 & 2.89 & 4.05 & 0.39 & 0.82 & 1.07 & 0.18 & 0.44 & 0.74 \\
\hline 3-Thujanone & 12.546 & 1118 & 1119 & 2.86 & 2.75 & 0.86 & 0.14 & 0.37 & 0.08 & 0.86 & 0.23 \\
\hline Camphor & 13.500 & 1145 & 1143 & 0.78 & 0.76 & 0.11 & 0.19 & 0.20 & 0.03 & 0.28 & 0.46 \\
\hline Hexyl isobutyrate & 13.609 & 1148 & 1150 & 0.12 & 0.02 & 0.07 & 0.03 & 0.00 & 0.00 & 0.02 & 0.16 \\
\hline Menthone & 13.820 & 1154 & 1154 & 0.46 & 0.09 & 0.00 & 0.36 & 0.32 & 0.04 & 0.02 & 0.00 \\
\hline trans-Pinocamphone & 13.900 & 1156 & 1160 & 0.12 & 0.21 & 0.20 & 0.13 & 0.07 & 0.03 & 0.23 & 0.02 \\
\hline Isomenthone & 14.054 & 1161 & 1164 & 0.00 & 0.02 & 0.18 & 0.01 & 0.00 & 0.00 & 0.00 & 0.03 \\
\hline$p$-Menthan-3-one & 14.166 & 1165 & 1166 & 0.55 & 0.13 & 0.07 & 0.02 & 0.00 & 0.00 & 0.01 & 0.00 \\
\hline Borneol & 14.251 & 1167 & 1167 & 0.33 & 0.03 & 0.01 & 0.02 & 0.00 & 0.00 & 0.04 & 0.06 \\
\hline 1-Nonanol & 14.391 & 1171 & 1173 & 1.02 & 1.01 & 0.07 & 0.28 & 0.23 & 0.03 & 0.39 & 0.04 \\
\hline Menthol & 14.474 & 1173 & 1175 & 0.00 & 0.02 & 0.09 & 0.08 & 0.01 & 0.02 & 0.01 & 0.20 \\
\hline
\end{tabular}


Table 3. Cont

\begin{tabular}{|c|c|c|c|c|c|c|c|c|c|c|c|}
\hline \multirow{3}{*}{ Compound } & \multirow{3}{*}{ RT } & \multirow{2}{*}{\multicolumn{2}{|c|}{ Retention Indexes }} & \multirow{2}{*}{ Fresh } & \multirow{2}{*}{ CPD-VMFD } & \multicolumn{3}{|c|}{ CD } & \multicolumn{3}{|c|}{ VMD } \\
\hline & & & & & & $40^{\circ} \mathrm{C}$ & $50^{\circ} \mathrm{C}$ & $60^{\circ} \mathrm{C}$ & $6 \mathrm{~W} / \mathrm{g}$ & $9 \mathrm{~W} / \mathrm{g}$ & $12 \mathrm{~W} / \mathrm{g}$ \\
\hline & & Exp. & Lit. & \multicolumn{8}{|c|}{ Concentration (mg $\left.100 \mathrm{~g}^{-1} \mathrm{db}\right)$} \\
\hline 3-Pinanone, cis & 14.517 & 1175 & 1173 & 0.00 & 0.00 & 0.01 & 0.02 & 0.01 & 0.00 & 0.00 & 0.01 \\
\hline Terpinen-4-ol & 14.639 & 1178 & 1177 & 0.00 & 0.03 & 0.00 & 0.01 & 0.00 & 0.00 & 0.00 & 0.00 \\
\hline$p$-Cymen-8-ol & 14.903 & 1186 & 1183 & 0.36 & 0.40 & 0.01 & 0.12 & 0.08 & 0.02 & 0.15 & 0.00 \\
\hline Hexanoic acid butyl ester & 15.070 & 1191 & 1189 & 0.41 & 0.01 & 0.01 & 0.21 & 0.10 & 0.01 & 0.22 & 0.13 \\
\hline Methyl salicylate & 15.211 & 1195 & 1192 & 2.29 & 1.15 & 0.50 & 0.49 & 1.14 & 0.05 & 0.04 & 0.00 \\
\hline Estragole & 15.336 & 1199 & 1196 & 1.52 & 1.55 & 0.17 & 0.57 & 0.56 & 0.10 & 0.59 & 0.27 \\
\hline 2-Octynoic acid-methyl ester & 15.558 & 1210 & 1212 & 0.29 & 0.75 & 0.09 & 0.30 & 0.22 & 0.07 & 0.35 & 0.17 \\
\hline Acetic acid, octyl ester & 15.766 & 1223 & 1210 & 0.16 & 1.15 & 0.10 & 0.32 & 0.29 & 0.04 & 0.41 & 0.22 \\
\hline Isogeraniol & 16.559 & 1235 & 1240 & 0.00 & 0.01 & 0.00 & 0.00 & 0.01 & 0.00 & 0.00 & 0.01 \\
\hline $\begin{array}{c}\text { Butanoic acid, 2-methyl-, } \\
\text { hexyl ester }\end{array}$ & 16.628 & 1238 & 1236 & 0.04 & 0.00 & 0.00 & 0.01 & 0.09 & 0.00 & 0.00 & 0.01 \\
\hline D-Carvone & 16.893 & 1245 & 1246 & 0.53 & 0.31 & 0.14 & 0.28 & 0.16 & 0.06 & 0.37 & 0.04 \\
\hline Isopentyl hexanoate & 17.158 & 1253 & 1252 & 0.00 & 0.00 & 0.00 & 0.01 & 0.00 & 0.00 & 0.00 & 0.00 \\
\hline Linalyl acetate & 17.271 & 1257 & 1257 & 0.59 & 0.01 & 0.00 & 0.33 & 0.15 & 0.01 & 0.00 & 0.15 \\
\hline iso-3-Thujanol acetate & 17.577 & 1265 & 1267 & 0.48 & 0.61 & 0.02 & 0.20 & 0.16 & 0.01 & 0.24 & 0.14 \\
\hline neo-3-Thujanol acetate & 17.742 & 1271 & - & 0.05 & 0.00 & 0.04 & 0.00 & 0.00 & 0.00 & 0.03 & 0.00 \\
\hline $\begin{array}{c}\text { Benzeneacetaldehyde, } \\
\alpha \text {-ethylidene- }\end{array}$ & 17.826 & 1273 & 1279 & 0.34 & 0.21 & 0.10 & 0.00 & 0.01 & 0.02 & 0.12 & 0.03 \\
\hline neo-iso-3-Thujanol acetate & 18.288 & 1280 & - & 0.09 & 0.01 & 0.01 & 0.01 & 0.01 & 0.00 & 0.00 & 0.00 \\
\hline Anethole & 18.300 & 1287 & 1286 & 0.22 & 0.00 & 0.13 & 0.06 & 0.03 & 0.01 & 0.10 & 0.04 \\
\hline 2-Undecanone & 18.524 & 1293 & 1294 & 0.22 & 0.40 & 0.23 & 0.44 & 0.32 & 0.11 & 0.27 & 0.10 \\
\hline$\alpha$-Cubebene & 20.258 & 1357 & 1351 & 2.20 & 2.02 & 0.32 & 0.39 & 0.56 & 0.13 & 0.80 & 0.38 \\
\hline Propanoic acid & 21.010 & 1378 & 1380 & 0.29 & 0.82 & 0.07 & 0.17 & 0.06 & 0.21 & 0.64 & 0.14 \\
\hline Copaene & 21.137 & 1383 & 1376 & 5.37 & 4.26 & 0.50 & 0.70 & 1.41 & 0.34 & 1.87 & 0.74 \\
\hline$\beta$-Bourbonene & 21.318 & 1390 & 1384 & 1.87 & 7.82 & 0.63 & 0.48 & 0.22 & 0.52 & 1.35 & 0.59 \\
\hline$\beta$-Cubebene & 21.444 & 1391 & 1389 & 5.15 & 4.11 & 0.37 & 0.87 & 1.04 & 0.03 & 1.34 & 0.96 \\
\hline cis- $\alpha$-Bergamotene & 21.845 & 1409 & 1415 & 0.48 & 0.18 & 0.02 & 0.09 & 0.04 & 0.11 & 0.22 & 0.09 \\
\hline Caryophyllene & 21.970 & 1417 & 1419 & 2.64 & 1.45 & 0.25 & 0.26 & 0.47 & 0.03 & 0.58 & 0.30 \\
\hline$\beta$-Duprezianene & 22.190 & 1427 & 1423 & 1.83 & 0.22 & 0.06 & 0.12 & 0.01 & 0.41 & 0.13 & 0.65 \\
\hline$\beta$-Gerjunene & 22.399 & 1437 & - & 0.19 & 0.14 & 0.01 & 0.02 & 0.03 & 0.00 & 0.03 & 0.03 \\
\hline Isogermacrene D & 22.523 & 1444 & 1448 & 0.08 & 0.00 & 0.00 & 0.00 & 0.00 & 0.00 & 0.00 & 0.01 \\
\hline Neoclovene & 22.649 & 1450 & 1454 & 0.17 & 0.00 & 0.00 & 0.12 & 0.03 & 0.00 & 0.03 & 0.01 \\
\hline Alloaromadendrene & 22.830 & 1457 & 1461 & 2.59 & 0.93 & 0.09 & 0.14 & 0.07 & 0.13 & 0.60 & 0.12 \\
\hline Sesquisabinene & 22.886 & 1462 & 1464 & 3.93 & 1.30 & 0.19 & 0.17 & 0.12 & 0.19 & 0.94 & 0.33 \\
\hline 9-epi-Caryophyllene & 23.054 & 1470 & 1467 & 3.03 & 2.36 & 0.36 & 0.40 & 0.62 & 0.15 & 0.94 & 0.32 \\
\hline$\gamma$-Muurolene & 23.275 & 1480 & 1477 & 0.11 & 0.06 & 0.01 & 0.00 & 0.02 & 0.00 & 0.01 & 0.01 \\
\hline$\gamma$-Curcumene & 23.330 & 1483 & 1480 & 0.35 & 0.21 & 0.04 & 0.03 & 0.05 & 0.01 & 0.08 & 0.04 \\
\hline$\alpha$-Amorphene & 23.443 & 1489 & 1482 & 10.55 & 0.97 & 0.52 & 0.74 & 0.90 & 0.48 & 2.00 & 1.39 \\
\hline$\gamma$-Amorphene & 23.665 & 1498 & 1496 & 2.20 & 1.63 & 0.39 & 0.33 & 0.54 & 0.15 & 0.76 & 0.56 \\
\hline
\end{tabular}


Table 3. Cont.

\begin{tabular}{|c|c|c|c|c|c|c|c|c|c|c|c|}
\hline \multirow{3}{*}{ Compound } & \multirow{3}{*}{ RT } & \multirow{2}{*}{\multicolumn{2}{|c|}{ Retention Indexes }} & \multirow{2}{*}{ Fresh } & \multirow{2}{*}{ CPD-VMFD } & \multicolumn{3}{|c|}{$\mathrm{CD}$} & \multicolumn{3}{|c|}{ VMD } \\
\hline & & & & & & $40^{\circ} \mathrm{C}$ & $50^{\circ} \mathrm{C}$ & $60^{\circ} \mathrm{C}$ & $6 \mathrm{~W} / \mathrm{g}$ & $9 \mathrm{~W} / \mathrm{g}$ & $12 \mathrm{~W} / \mathrm{g}$ \\
\hline & & Exp. & Lit. & \multicolumn{8}{|c|}{ Concentration (mg $\left.100 \mathrm{~g}^{-1} \mathrm{db}\right)$} \\
\hline$\alpha$-Muurolene & 23.762 & 1505 & 1499 & 0.09 & 0.01 & 0.03 & 0.00 & 0.04 & 0.00 & 0.02 & 0.01 \\
\hline$\beta$-Bisabolene & 23.874 & 1513 & 1509 & 0.21 & 0.02 & 0.01 & 0.05 & 0.02 & 0.00 & 0.07 & 0.08 \\
\hline$\delta$-Cadinene & 24.011 & 1522 & 1524 & 0.20 & 0.02 & 0.01 & 0.01 & 0.01 & 0.00 & 0.01 & 0.02 \\
\hline cis-Calamenene & 24.151 & 1530 & 1531 & 5.53 & 5.71 & 0.99 & 1.01 & 1.71 & 0.28 & 1.70 & 0.92 \\
\hline$\alpha$-Cadinene & 24.319 & 1540 & 1538 & 2.11 & 0.73 & 0.13 & 0.11 & 0.21 & 0.08 & 0.31 & 0.20 \\
\hline$\alpha$-Himachalene & 24.433 & 1550 & 1549 & 1.01 & 0.13 & 0.03 & 0.03 & 0.03 & 0.04 & 0.13 & 0.07 \\
\hline Widdrol & 25.413 & 1618 & 1610 & 0.05 & 0.08 & 0.00 & 0.01 & 0.01 & 0.01 & 0.03 & 0.03 \\
\hline Isopropyl myristate & 27.409 & 1825 & 1827 & 0.28 & 0.31 & 0.07 & 0.12 & 0.08 & 0.33 & 0.61 & 0.25 \\
\hline TOTAL & & & & 176.81 & 179.02 & 44.47 & 57.83 & 53.32 & 16.15 & 48.02 & 29.94 \\
\hline
\end{tabular}

RT—retention time; Exp.—experimental; Lit.—retention indices according to NIST 14 database; CD—convective drying; VMD—vacuum microwave drying; CPD—convective pre-drying; VMFD—vacuum microwave finish drying. 


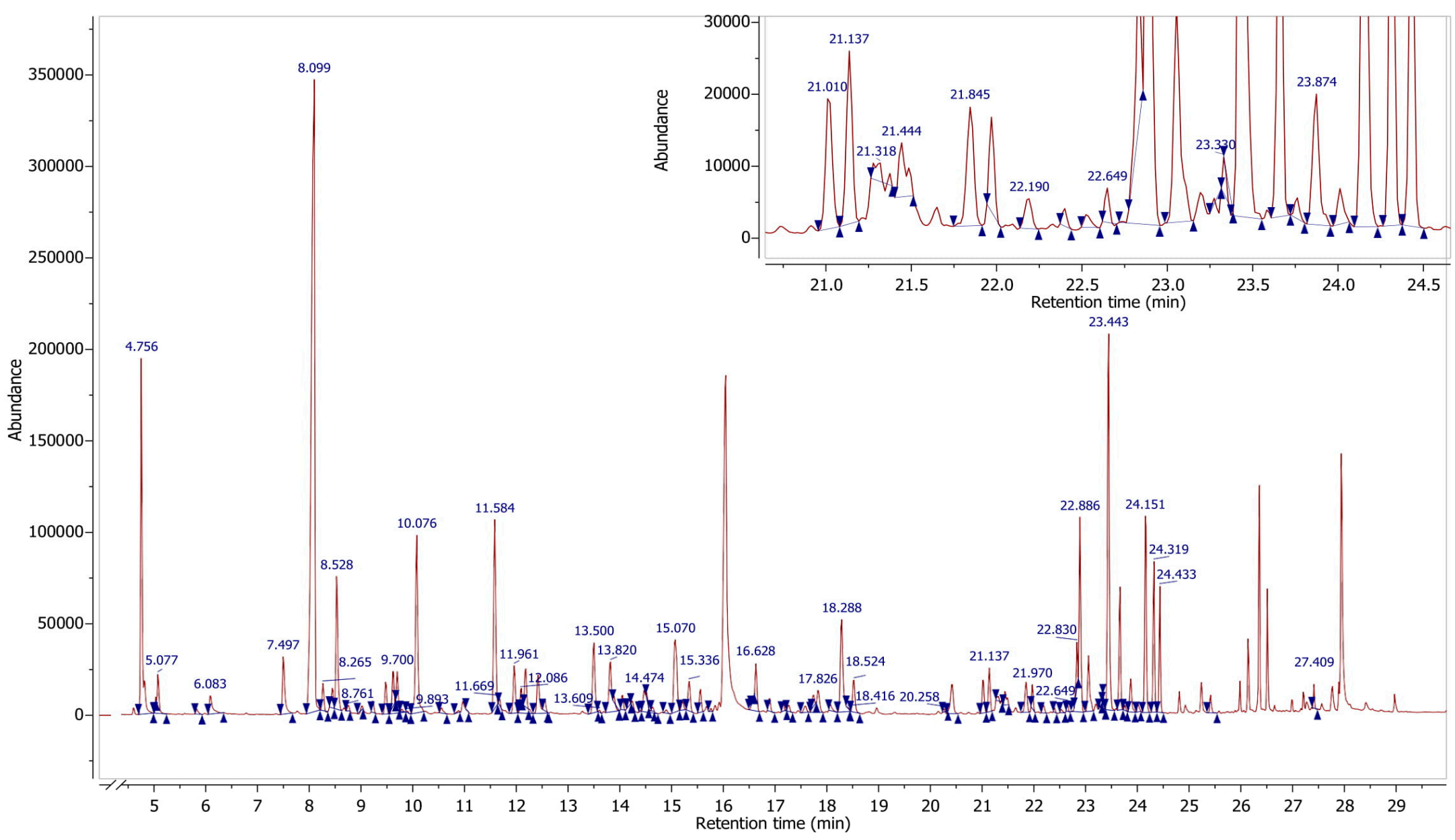

Figure 6. A typical gas chromatography—-mass spectrometry (GC-MS) chromatogram of fresh P. nodiflora. 
Leaves dried using CPD-VMFD (179.02 $\left.\mathrm{mg} 100 \mathrm{~g}^{-1} \mathrm{db}\right)$ achieved higher retention of volatiles compared with fresh leaves (176.81 mg $100 \mathrm{~g}^{-1} \mathrm{db}$ ), but the differences in values were marginal (Table 3). Thermal treatment of leaves during CPD-VMFD may have inactivated polyphenol oxidase (PPO), thereby reducing enzymatic degradation of volatiles [27]. In addition, short thermal treatment, achieved by the introduction of VMFD assured that volatiles were not exposed to high temperature for an excessively long period.

Consistent with the literature, $\mathrm{CD}$ and VMD led to considerable losses of volatiles, evidenced by the drying of thyme [17], basil [13], and rosemary [35]. In this study, CD retained a higher amount of volatiles than did VMD. A similar result was reported in the drying of rosemary [35]. In another study, VMD was shown to retain higher total volatiles because of the fast drying process at a mild temperature [18]. However, in this study, average temperature throughout VMD, irrespective of microwave power, was $46^{\circ} \mathrm{C}$. Slightly higher temperatures of $\mathrm{CD}$ at 50 and $60^{\circ} \mathrm{C}$ and CPD-VMFD at $50{ }^{\circ} \mathrm{C}$ were advantageous in forming a partially dried surface layer on leaves that function as a barrier, thereby limiting the diffusion of volatiles and minimizing their loss [36]. Furthermore, the formation of a crust layer is characteristic of products dried using CD. Parameters in CD and VMD also affect the total concentration of volatiles. A moderate temperature of $50{ }^{\circ} \mathrm{C}$ and microwave power of $9 \mathrm{~W} / \mathrm{g}$ were preferable in yielding higher total volatiles. At these conditions, leaves were subjected to moderate temperature at a relatively short time. It was suggested that VMD led to higher amount of volatiles loss as microwave treatment causes a more porous structure in plant tissue because of the high internal vapor formed during the drying process. The higher porosity of tissue structure of vacuum microwave-dried leaves, compared to convective-dried leaves, could be a possible reason that a higher amount of volatiles could escape to the surrounding medium [37,38].

Analysis of volatile compounds of dried samples showed that CPD-VMFD and CD $50{ }^{\circ} \mathrm{C}$ yielded the highest volatile concentrations. Therefore, both methods were used to determine the influence on phytosterols concentration. Table 4 shows the identified phytosterols in P. nodiflora and their respective concentrations. The total concentrations of phytosterols in fresh leaves were $1237.39 \mathrm{mg} 100 \mathrm{~g}^{-1} \mathrm{db}$. $\beta$-Sitosterol was the major phytosterol in fresh and dried samples, followed by stigmasterol and campesterol. CPD-VMFD was able to retain a higher total yield of phytosterols $\left(711.07 \mathrm{mg}^{\left.100 \mathrm{~g}^{-1} \mathrm{db}\right)}\right.$ compared with $\mathrm{CD} 50{ }^{\circ} \mathrm{C}$ samples $\left(668.66 \mathrm{mg} 100 \mathrm{~g}^{-1} \mathrm{db}\right)$. Due to the chemical structures of phytosterols, such as the unsaturation at the side chain or ring, these compounds may undergo oxidation when exposed to air and heat treatment at high temperatures. The oxidation process of phytosterols is reported to increased when phytosterols are subjected to heat and the stability of phytosterols is also influenced by the temperature and time of heat treatment [39]. In this study, microwave treatment during VMFD benefited the retainment of higher phytosterol content. Lower temperature and reduced oxygen condition during VMFD may have minimized the thermo-oxidation of phytosterols, thereby increasing the stability of phytosterols. This result is in agreement with the results obtained by Soupas et al. [40], Rudzińska, Przybylski, and Wasowicz [41], which all reported that phytosterol concentration decreased with increased drying temperature and prolonged drying time. 
Table 4. Phytosterols profile of $P$. nodiflora dried using different drying methods.

\begin{tabular}{|c|c|c|c|c|c|}
\hline \multirow{2}{*}{ Compound } & \multicolumn{2}{|c|}{ Retention Time (min) } & Fresh & $\mathrm{CD} 50^{\circ} \mathrm{C}$ & CPD-VMFD \\
\hline & \multirow{2}{*}{$\begin{array}{c}\text { Exp. } \\
28.99\end{array}$} & \multirow{2}{*}{$\begin{array}{c}\text { Lit. } \\
28.98\end{array}$} & \multicolumn{3}{|c|}{ Concentration (mg $\left.100 \mathrm{~g}^{-1} \mathrm{db}\right)$} \\
\hline$\beta$-Sitosterol & & & 529.67 & 268.88 & 280.99 \\
\hline Stigmasterol & 28.06 & 28.15 & 323.47 & 173.34 & 191.72 \\
\hline Campesterol & 27.58 & 27.58 & 205.81 & 100.24 & 99.65 \\
\hline Betulin & 31.16 & 31.17 & 30.68 & 37.30 & 39.17 \\
\hline Desmosterol & 26.64 & 26.63 & 76.89 & 35.59 & 37.94 \\
\hline Cycloartenol & 30.00 & 30.05 & 28.15 & 24.15 & 22.43 \\
\hline Lanosterol & 26.89 & 26.88 & 40.58 & 19.88 & 20.31 \\
\hline$\alpha$-tocopherol & 25.97 & 25.95 & 2.14 & 9.30 & 18.86 \\
\hline Total & - & - & 1237.39 & 668.66 & 711.07 \\
\hline
\end{tabular}

Exp.-experimental; Lit.-Retention time according to Adams [42]; CD—convective drying; CPD—convective pre-drying; VMFD—vacuum microwave finish drying.

\subsection{Fatty Acid Analysis}

Thermal drying has little effect on the concentration of fatty acids because it was reported that fatty acids remained stable even at a high temperature of $325^{\circ} \mathrm{C}$ [43]. In another study, less than $1 \%$ of long-chain fatty acids were lost when subjected to thermal hydrolysis at $90{ }^{\circ} \mathrm{C}$ for 30 min [44]. Therefore, drying temperatures of CD, VMD, and CPD-VMFD, applied in this study, can be assumed to have no degradative effect on fatty acids. Profiles of the relative abundance of fatty acids identified in P. nodilfora leaves are presented in Table 5. The major fatty acid present was $\alpha$-linolenic acid, followed by palmitic acid, with boiling points of 231 and $351.5^{\circ} \mathrm{C}$, respectively $[45,46]$. Therefore, this further proves that the temperatures applied in this study could not have affected the total concentrations of $\alpha$-linolenic acid and palmitic acid. $\alpha$-linolenic acid is a plant-derived omega-3 fatty acid and is an antioxidant, widely researched for its role in mediating cardiovascular disease [47].

Table 5. Profile of fatty acid methyl esters of $P$. nodiflora.

\begin{tabular}{cc}
\hline Compound & Total Area (\%) \\
\hline a-linolenic acid & 48.30 \\
Palmitic acid & 21.99 \\
Linolelaidic acid & 8.80 \\
Oleic acid & 7.98 \\
Stearic acid & 5.60 \\
11-hexadecenoic acid, methyl ester, (11Z)- & 1.53 \\
Myristic acid & 1.41 \\
Behenic acid & 0.71 \\
Erucic acid & 0.69 \\
Arachidic acid & 0.68 \\
Palmitoleic acid & 0.64 \\
Elaidic acid & 0.43 \\
Heptadecanoic acid & 0.26 \\
cis-10-heptadecenoic acid & 0.25 \\
Lauric acid & 0.22 \\
Pentadecanoic acid & 0.22 \\
Capric acid & 0.12 \\
Linolelaidic acid & 0.09 \\
Tridecanoic acid & 0.08 \\
\hline
\end{tabular}

\subsection{Color Analysis}

Color values of fresh and dried P. nodiflora leaves are shown in Table 6. Parameters investigated include lightness $\left(L^{*}\right), 0$ (black) to 100 (white); greenness or redness $\left(a^{*}\right),-60$ (green) to 60 (red); 
and blueness or yellowness $\left(b^{*}\right),-60$ (blue) to 60 (yellow). Color changes in herbs subjected to drying are usually due to the loss of green pigments and carotenoids or enzymatic browning [48]. However, the shaping of the color profile of the dried product depends not only on the time and drying conditions but also on the amount of residual water, which can be estimated by the water activity values.

Table 6. Color parameters of $P$. nodiflora leaves measured after applications of different drying methods.

\begin{tabular}{cccc}
\hline \multirow{2}{*}{ Drying Conditions } & \multicolumn{3}{c}{ Color Parameters } \\
\cline { 2 - 4 } & $\boldsymbol{L}^{*}$ & $\boldsymbol{a}^{*}$ & $\boldsymbol{b}^{*}$ \\
\hline Fresh & $46.90 \pm 0.09^{\mathrm{c}}$ & $-6.33 \pm 0.09^{\mathrm{a}}$ & $18.52 \pm 0.12^{\mathrm{a}}$ \\
$\mathrm{CD} 40^{\circ} \mathrm{C}$ & $45.23 \pm 0.24^{\mathrm{a}, \mathrm{b}, \mathrm{c}}$ & $-6.35 \pm 0.07^{\mathrm{a}}$ & $15.92 \pm 0.09^{\mathrm{b}}$ \\
CD $50^{\circ} \mathrm{C}$ & $46.56 \pm 0.13^{\mathrm{c}}$ & $-5.5 \pm 0.04^{\mathrm{b}, \mathrm{c}}$ & $16.05 \pm 0.13^{\mathrm{b}}$ \\
CD $60^{\circ} \mathrm{C}$ & $46.05 \pm 0.08^{\mathrm{b}, \mathrm{c}}$ & $-5.21 \pm 0.03^{\mathrm{c}}$ & $15.86 \pm 0.06^{\mathrm{b}}$ \\
VMD $6 \mathrm{~W} / \mathrm{g}$ & $45.62 \pm 0.16^{\mathrm{a}, \mathrm{b}, \mathrm{c}}$ & $-5.96 \pm 0.19^{\mathrm{a}, \mathrm{b}}$ & $17.17 \pm 0.30^{\mathrm{d}}$ \\
VMD 9 W/g & $44.54 \pm 0.04^{\mathrm{a}, \mathrm{b}}$ & $-5.5 \pm 0.04^{\mathrm{b}, \mathrm{c}}$ & $16.14 \pm 0.05^{\mathrm{b}}$ \\
VMD 12 W/g & $43.94 \pm 0.22^{\mathrm{a}}$ & $-5.86 \pm 0.05^{\mathrm{b}}$ & $16.31 \pm 0.06^{\mathrm{b}, \mathrm{c}}$ \\
CPD-VMFD & $46.49 \pm 0.16^{\mathrm{c}}$ & $-7.02 \pm 0.02^{\mathrm{d}}$ & $16.77^{\mathrm{c}} \pm .15^{\mathrm{c}, \mathrm{d}}$ \\
\hline
\end{tabular}

CD—convective drying; VMD—vacuum microwave drying; CPD—convective pre-drying; VMFD—vacuum microwave finish drying; mean values with different alphabets $(a, b, c, d)$ within each column is significantly different $(p<0.05)$, according to Tukey's test.

Fresh leaves recorded the highest $L^{*}$ value, whereas VMD at $12 \mathrm{~W} / \mathrm{g}$ resulted in the darkest colored leaves with lowest $L^{*}$ value, but these values were not significantly different from those of VMD 6 and $9 \mathrm{~W} / \mathrm{g}$ and $\mathrm{CD} 40{ }^{\circ} \mathrm{C}$. These conditions promote PPO activity, which results in browning characteristics of dried products [49,50]. An increase in microwave power, from 6 to $12 \mathrm{~W} / \mathrm{g}$, associated with increased maximal temperature of dried material from 52 to $57^{\circ} \mathrm{C}$, decreased the $L^{*}$ value from 45.62 to 43.94 . At higher microwave powers, increased amounts of absorbed energy used to vaporize water were observed, which may have been sufficiently large to increase the sample temperatures further during the falling rate period, thereby producing darker leaves [38]. This finding was evidenced in a previous study, in which burnt spots were observed on mint leaves after VMD [38].

The loss in green color was assumed to be related to the loss of chlorophyll [48], as indicated by an increase in $a^{*}$ values (Table 6) which is thought to be associated with decreased $\mathrm{a}_{\mathrm{w}}$ (Table 7). This relationship was confirmed for CD and VMD samples because the decrease in $a_{w}$ from 0.2252 to 0.1081 and from 0.2780 to 0.2353 resulted in increased $a^{*}$ values from -6.35 to -5.21 and from -5.96 to -5.86 , respectively. The lowest values of $a^{*}$ were -6.35 and -7.02 , which were found for CD $40{ }^{\circ} \mathrm{C}$ and CPD-VMFD samples, respectively. In the case of $\mathrm{CD} 40^{\circ} \mathrm{C}$, the processing temperature was the lowest, whereas combined drying CPD-VMFD underwent at a relatively short time and moderate conditions in terms of temperature and microwave power, thereby leading to lower extents of chlorophyll degradation.

Table 7. Water activity of different drying methods.

\begin{tabular}{cc}
\hline Drying Method & Water Activity, $\mathbf{a}_{\mathbf{w}}$ \\
\hline Fresh & $0.9879 \pm 0.006^{\mathrm{a}}$ \\
$\mathrm{CD} 40^{\circ} \mathrm{C}$ & $0.2252 \pm 0.003^{\mathrm{b}, \mathrm{d}}$ \\
$\mathrm{CD} 50{ }^{\circ} \mathrm{C}$ & $0.1485 \pm 0.010^{\mathrm{c}}$ \\
$\mathrm{CD} 60^{\circ} \mathrm{C}$ & $0.1081 \pm 0.010^{\mathrm{c}}$ \\
$\mathrm{VMD} 6 \mathrm{~W} / \mathrm{g}$ & $0.2780 \pm 0.001^{\mathrm{d}}$ \\
$\mathrm{VMD} 9 \mathrm{~W} / \mathrm{g}$ & $0.1743 \pm 0.044^{\mathrm{b}, \mathrm{c}}$ \\
$\mathrm{VMD} 12 \mathrm{~W} / \mathrm{g}$ & $0.2353 \pm 0.008^{\mathrm{b}, \mathrm{d}}$ \\
$\mathrm{CPD}-\mathrm{VMFD}$ & $0.1339 \pm 0.020^{\mathrm{c}}$ \\
\hline
\end{tabular}

CD—convective drying; VMD—vacuum microwave drying; CPD—convective pre-drying; VMFD—vacuum microwave finish drying; mean values with different alphabets $(a, b, c, d)$ within each column is significantly different $(p<0.05)$, according to Tukey's test. 
Carotenoids, which tend to have yellowish color, were far better preserved in VMD $6 \mathrm{~W} / \mathrm{g}$, as indicated by a higher $b^{*}$ value. High vacuum conditions and lower temperatures of VMD compared with CD methods guaranteed improved preservation of carotenoids. In the presence of oxygen, the susceptibility of carotenoids to oxidation is high [51]; therefore, we can assume that higher oxidation occurred during $C D$. However, shortening drying time of $C D$ by applying vacuum microwaves increased the value of $b^{*}$ coordinate, thereby indicating the effectiveness of CPD-VMFD in preserving natural colorants.

\subsection{Water Activity Analysis}

Water activity $\left(\mathrm{a}_{\mathrm{w}}\right)$ measures the extent of water removal and the amount of residual moisture of dried products [10]. To eliminate the possibility of microbial growth and unfavorable enzymatic activities, dried products should have low $\mathrm{a}_{\mathrm{w}}$, ranging from 0.60 to 0.80 . Spoilage bacteria are inhibited below $a_{w}$ of 0.91 and most types of mold are inhibited at $a_{w}$ of 0.80 [51]. However, for dried leaves or tea products, the suggested $\mathrm{a}_{\mathrm{w}}$ should be below 0.267 [52]. The lowest $\mathrm{a}_{\mathrm{w}}$ recorded was for convective-dried (CD) samples at $60^{\circ} \mathrm{C}$ (Table 7). Leaves dried at CD 50 and $60^{\circ} \mathrm{C}$ and CPD-VMFD have significantly lower $\mathrm{a}_{\mathrm{w}}$, because drying temperatures coupled with extended drying durations of $C D$ ensured minimal residual moisture in leaves. Increasing the hot-air temperature during CD corresponded to lower $\mathrm{a}_{\mathrm{w}}$, because the temperature difference between the leaf material and surrounding heated air increased, which resulted in greater heat and moisture transfer. Thus, higher evaporation of water occurs, leaving material with a lower amount of moisture. The low $\mathrm{a}_{\mathrm{w}}$ values obtained for all drying methods suggest that samples were microbiologically stable, and that a limited amount of residual water was present for undesirable chemical reactions to occur.

\section{Materials and Methods}

\subsection{Chemicals and Reagents}

2,2'-Azinobis (3-ethylbenzthiazoline-6-sulfonic acid (ABTS)), potassium persulfate, 6-hydroxy-2,5,7,8-tetramethylchroman-2-carboxylic acid (Trolox), ferric reducing/antioxidant power (FRAP) reagent, acetate buffer, acetic acid, 2,4,6-tripyridyl-1,3,5-triazine (TPTZ), Folin-Ciocalteu reagent, sodium carbonate, gallic acid, $p$-methoxyphenol, chloroform, potassium hydroxide, hexane, sodium chloride, methanol, hydrochloric acid, boron trifluoride-methanol solution $\left(\mathrm{BF}_{3} / \mathrm{MeOH}\right)$, magnesium sulfate, pyradine, and N,O-Bis(trimethylsilyl)trifluoroacetamide (BSTFA)) were purchased from Sigma-Aldrich (Steinheim, Germany).

\subsection{Plant Material Preparation}

Fresh leaves of $P$. nodiflora were purchased from TKC Nursery (Negeri Sembilan) and identified at the Forest Research Institute Malaysia with voucher number (049/17). Leaves were cleaned and vacuum-oven dried at $60^{\circ} \mathrm{C}$ for $24 \mathrm{~h}$ to obtain the initial moisture content as determined by Equation (1).

$$
\text { Initial moisture content }=\frac{\text { Initial weight }- \text { dry matter weight }}{\text { dry matter weight }}
$$

\subsection{Drying Methods}

Drying was conducted in the Institute of Agriculture Engineering (Wroclaw, Poland). Leaves were dried in $40 \mathrm{~g}$ portions using three methods, namely CD, VMD, and CPD-VMFD. Drying was ended when the mass loss of consecutive samples was $0.05 \mathrm{~g}$ or less. For VMD and CPD-VMFD, the sample temperature was measured with an infrared thermometer (Flir i50, Portland, OR, USA) after removing from the dryer, thereby providing an indication of the maximal temperature. 


\subsubsection{Convective Drying (CD)}

Leaves were dried at 40,50 , and $60{ }^{\circ} \mathrm{C}$ in a convective hot-air oven designed and constructed in the Institute of Agriculture Engineering (Wroclaw, Poland). Leaves were spread on a wire mesh tray and placed on top of drying chambers with an air velocity of $1.8 \mathrm{~ms}^{-1}$.

\subsubsection{Vacuum-Microwave Drying (VMD)}

Leaves were dried in a vacuum-microwave dryer (Plazmatronika, Wroclaw, Poland) at microwave powers of 6,9, and $12 \mathrm{~W} / \mathrm{g}$. Leaves were placed in an organic glass container, connected to a vacuum system that was rotated at a speed of $6 \mathrm{rpm}$. The pressure in the vacuum drum was varied from 4 to $6 \mathrm{kPa}$. An electric fan at the bottom of the dryer provided an air stream velocity and temperature of $1 \mathrm{~ms}^{-1}$ and $22{ }^{\circ} \mathrm{C}$, respectively, to prevent local overheating of leaves.

\subsubsection{Two-Stage Drying-Convective Pre-Drying Followed by Vacuum-Microwave Finish} Drying (CPD-VMFD)

$\mathrm{CPD}$ of leaves was conducted with the same procedures as $\mathrm{CD}$ at $50{ }^{\circ} \mathrm{C}$ for $90 \mathrm{~min}$ to achieve a moisture content of $0.537 \mathrm{~kg}$ water kg ${ }^{-1} \mathrm{dw}$. Pre-dried leaves were finish dried in a vacuum-microwave dryer (Plazmatronika, Wroclaw, Poland) at $9 \mathrm{~W} / \mathrm{g}$, with similar operating conditions to those for VMD. Intermediate hot-air temperature at $50{ }^{\circ} \mathrm{C}$ and microwave wattage at $9 \mathrm{~W} / \mathrm{g}$ were used in CPD-VMFD, as both parameter levels ensured the highest concentration of volatile compounds in the dried product (Table 3).

\subsection{Modelling of Drying Kinetics}

Drying kinetics were determined based on the mass losses of leaves throughout the drying process. Drying curves were plotted as functions of moisture ratio against time. Moisture ratios $M R$ were determined from Equation (2):

$$
M R=\frac{M(t)-M_{e}}{M_{0}-M_{e}}
$$

where $M(t)$ indicates moisture content after drying time $t, M_{0}$ denotes initial moisture content and $M_{e}$ denotes equilibrium moisture content, determined at the final stage of the drying process as an asymptotic value of the function fitted to the experimental points using Table Curve 2D Windows v2.03 (Jandel Scientific Software, San Rafael, CA, USA). To select the most suitable model, three commonly used thin layer models, namely Lewis (Equation (3)), modified Page (Equation (4)), and Henderson and Pabis (Equation (5)) were examined.

$$
\begin{gathered}
M R=\exp (-k \cdot t) \\
M R=a \cdot \exp \left(-k \cdot t^{n}\right) \\
M R=a \cdot \exp (-k \cdot t)
\end{gathered}
$$

where $M R$ is moisture ratio, $a$ is model constant, $k$ denotes drying constant, and $n$ represents the dimensionless empirical constant.

\subsection{Determination of Energy Consumption}

\subsubsection{Energy Consumption of CD}

Energy consumed during $C D, E_{C}$ (kilojoules) was determined as follows [53]:

$$
E_{C}=\left(\frac{N_{f}}{6}+N_{h}\right) \times t
$$


where $N_{f}$ (kilowatts) is the power consumption of the fan supplying air to the six pipes, fixed with an electric heater of power consumption $N_{h}$ (kilowatts), whereas $t$ is the time of drying (seconds).

\subsubsection{Energy Consumption of VMD}

Energy consumed during VMD, $E_{V M}$ (kilojoules) was determined as follows [53]:

$$
E_{V M}=\left(\frac{N_{M}}{\eta_{M}}+N_{V}+N_{e}\right) \times t
$$

where $N_{M}$ is the output power of magnetrons (kilowatts), $\eta_{M}$ is the efficiency of magnetrons, $N_{V}$ is the power consumption of vacuum pump (kilowatts), $N_{e}$ is the power consumption of electric engine rotating the container (kilowatts), and $t$ is drying time (seconds).

\subsubsection{Specific Energy Consumption of CD, VMD, and CPD-VMFD}

Specific energy consumption is calculated to determine the energy consumption per unit mass of fresh weight and energy consumption per unit mass of water. The specific energy consumption expressed in $\mathrm{kJ} / \mathrm{g}$ fresh weight of sample can be useful in prediction of energy expenditure for drying of specified plant material. On the other hand, specific energy consumption expressed in $\mathrm{kJ} / \mathrm{g}$ water contained in sample enables comparison of energy consumption for different plant materials with different moisture content.

Specific energy consumptions of $\mathrm{CD}, E_{C_{m}}\left(\mathrm{~kJ} \mathrm{~g}^{-1} f w\right)$, and $E_{C_{W}}\left(\mathrm{~kJ} \mathrm{~g}^{-1}\right.$ water $)$ were calculated based on Equations (8) and (9) [53], and the specific energy consumptions of VMD, $E_{V M_{m}}\left(\mathrm{~kJ} \mathrm{~g}^{-1} \mathrm{fw}\right)$ and $E_{V M_{W}}\left(\mathrm{~kJ} \mathrm{~g}^{-1}\right.$ water), Equations (10) and (11) [53], were calculated as (1) ratio of energy consumption to the initial sample mass, $m$ (grams); and (2) ratio of energy consumption to the mass of water $W$ (grams) removed from the sample.

$$
\begin{aligned}
E_{C_{m}} & =\frac{E_{C}}{m} \\
E_{C_{W}} & =\frac{E_{C}}{W} \\
E_{V M_{m}} & =\frac{E_{V M}}{m} \\
E_{V M_{W}} & =\frac{E_{V M}}{\mathrm{~W}}
\end{aligned}
$$

Specific energy consumptions for CPD-VMFD, $E_{C-V M_{m}}\left(\mathrm{~kJ} \mathrm{~g}^{-1} f w\right)$ and $E_{C-V M_{W}}\left(\mathrm{~kJ} \mathrm{~g}^{-1}\right.$ water $)$, are as shown in Equations (12) and (13), respectively [53]. Both equations are the ratios of the sum of energy $E_{C}$ and $E_{V M}$ to the mass of initial sample, $m$ (grams) and total mass of water (grams) from CPD, $W_{C}$ and VMFD, $W_{V M}$ removed from the sample, respectively.

$$
\begin{aligned}
E_{C-V M_{m}} & =\frac{E_{C}+E_{V M}}{m} \\
E_{C-V M_{W}} & =\frac{E_{C}+E_{V M}}{W_{C}+W_{V M}}
\end{aligned}
$$

\subsection{Extraction of Polyphenol Compounds}

Ground samples $(0.3 \mathrm{~g})$ were measured into tubes. Then, $80 \%$ aqueous methanol $(0.7 \mathrm{~mL})$ was added with $1 \% \mathrm{HCl}$ and stirred gently. Tubes with suspension were sonicated twice for $15 \mathrm{~min}$ and left at $4{ }^{\circ} \mathrm{C}$ for $24 \mathrm{~h}$. The extract was centrifuged for $10 \mathrm{~min}$ at 15,000 rpm (MPW-360R, Warsaw, Poland) and supernatants were collected. 


\subsection{Antioxidant Activity Analysis}

\subsubsection{ABTS ${ }^{\bullet+}$ Radical-Scavenging Assay}

ABTS assay was conducted as previously described by Re at al. [54]. ABTS was dissolved in water to form a concentration of $7 \mathrm{mM}$. ABTS stock solution was mixed with $2.45 \mathrm{mM}$ potassium persulfate to obtain ABTS radical cation $\left(\mathrm{ABTS}^{\bullet+}\right)$. This mixture was left to stand for $12-16 \mathrm{~h}$ in the dark at room temperature. The solution was diluted with distilled water to obtain an absorbance of $0.700 \pm 0.02$ at $734 \mathrm{~nm}$. Diluted radical solution $(3 \mathrm{~mL})$ was mixed with $20 \mu \mathrm{L}$ of the extracted supernatant. Absorbance was determined using a UV-vis spectrophotometer (Shimadzu, UV-2401 PC, Kyoto, Japan) at $734 \mathrm{~nm}$ after $6 \mathrm{~min}$. Results were expressed as micromolar Trolox per 100 grams of dry weight $(\mathrm{dw})$.

\subsubsection{FRAP Assay}

FRAP assay was performed as described previously by Benzie and Strain [55]. FRAP reagent was prepared by mixing acetate buffer $(300 \mu \mathrm{M}, \mathrm{pH} 3.6)$, solution of $10 \mu \mathrm{M} \mathrm{TPTZ}$ in $40 \mu \mathrm{M} \mathrm{HCl}$ and $20 \mu \mathrm{M}$ of $\mathrm{FeCl}_{3}$ (Sigma-Aldrich, Steinheim, Germany) at a ratio of 10:1:1 (v/v/v). The FRAP reagent $(300 \mu \mathrm{L})$ and sample solution $(10 \mu \mathrm{L})$ were mixed thoroughly. Absorbance was read at $593 \mathrm{~nm}$ using a UV-vis spectrophotometer (Shimadzu, UV-2401 PC, Kyoto, Japan) after $10 \mathrm{~min}$. A standard curve was constructed using different concentrations of Trolox.

\subsection{Analysis of Total Phenolic Content}

Total phenolic content was determined using the Folin-Ciocalteu method, previously described by Gao, Ohlander, Jeppsson, Björk, and Trajkovski [56]. Leaf extract $(0.1 \mathrm{~mL})$ was mixed with $2 \mathrm{~mL}$ of water and $0.2 \mathrm{~mL}$ of Folin-Ciocalteu reagent. The mixture was incubated at room temperature for $3 \mathrm{~min}$ and added with $1 \mathrm{~mL}$ of $20 \%$ sodium carbonate. Absorbance was measured using a UV-vis spectrophotometer (Shimadzu, UV-2401 PC, Kyoto, Japan) at $765 \mathrm{~nm}$ after $1 \mathrm{~h}$ of incubation at room temperature. Quantification was determined based on a gallic acid standard curve. Results were expressed as gallic acid equivalence (in milligrams per 100 grams of $\mathrm{dw}$ ).

\subsection{Analysis of Volatile Compounds}

Analysis of volatile compounds was conducted using headspace solid phase microextraction (HS-SPME). Approximately $0.25 \mathrm{~g}$ of crushed dried and fresh leaf samples were placed in vials with the internal standard; $p$-methoxyphenol $(2 \mu \mathrm{g})$. Vials were covered with PTFE/silicon septum and placed in a water bath at $60^{\circ} \mathrm{C}$ for equilibration (10 min). SPME fiber (Supelco, Bellefonte, PA, USA) with a vivinylbenzene/carboxen/polydimethylsiloxane (DVB/CAR/PDMS, 50/30 $\mu \mathrm{m}$, coating $2 \mathrm{~cm}$ ) (Supelco) was used. Prior to extraction, SPME fiber was conditioned by inserting into a GC injection port for $1 \mathrm{~h}$ at $220^{\circ} \mathrm{C}$. For each extraction, SPME fiber was inserted into a vial that contained a sample kept in a water bath at $60^{\circ} \mathrm{C}$ for $30 \mathrm{~min}$. Next, the fiber was drawn into a needle and injected into the injection port of a GC-MS at an injection temperature of $220^{\circ} \mathrm{C}$ for $3 \mathrm{~min}$. The GC-MS analysis was performed on a Varian CP-3800/Saturn 2000 (Varian, Wallnut Creek, CA, USA) equipped with a capillary column, ZB-5MS (30 m $\times 0.25 \mathrm{~mm}$ i.d $\times 0.25 \mu \mathrm{m}$ film thickness) (Phenomenex, Shim-Pol, Poland).

Our gradient temperature program was as follows. The initial oven temperature was $50{ }^{\circ} \mathrm{C}$, which was increased to $130{ }^{\circ} \mathrm{C}$ at a rate of $4{ }^{\circ} \mathrm{C} \mathrm{min}-1$. Then, the temperature was raised to $180{ }^{\circ} \mathrm{C}$ at $10^{\circ} \mathrm{C} \mathrm{min}-1$ and finally raised up to $280^{\circ} \mathrm{C}$ at a rate of $2{ }^{\circ} \mathrm{C} \mathrm{min}-1$. Samples were injected in split mode (1:10), and helium gas was used as the carrier gas at a flow rate of $1.0 \mathrm{~mL} \mathrm{~min}^{-1}$. Mass spectra were obtained in EI ionisation mode at $70 \mathrm{eV}$ within a scan range of $35-550 \mathrm{~m} / \mathrm{z}$. After each extraction, SPME fiber was prepared for the subsequent extractions by placing in the injection port of GC-MS for $15 \mathrm{~min}$ at $220^{\circ} \mathrm{C}$, to ensure complete elution of volatiles. Identification of all volatile constituents was based on a comparison of experimentally obtained compound mass spectra with mass spectra 
available in NIST14 database. Furthermore, the experimentally obtained retention index (RI) by Kovats was compared with RI available in the NIST WebBook and literature data [42].

\subsection{Extraction of Lipids}

Lipids were extracted using a previous method by Folch, Lees, and Stanley [57]. Lipids from ground leaves were extracted using 2:1 chloroform-methanol $(v / v)$ for $24 \mathrm{~h}$ and filtered thereafter. The resultant filtrate was subjected to vacuum rotary evaporator at $65{ }^{\circ} \mathrm{C}$ to remove extraction solvent. Crude lipids obtained were weighed and later saponified $\left(10 \mathrm{~min}\right.$ at $\left.80^{\circ} \mathrm{C}\right)$ with $10 \mathrm{~mL}$ of $0.5 \mathrm{M}$ $\mathrm{KOH} / \mathrm{MeOH}$, boiled with reflux for $5-10 \mathrm{~min}$ and left to cool at $12{ }^{\circ} \mathrm{C}$. The sample was placed in a separation funnel; hexane $(10 \mathrm{~mL})$ and water $(10 \mathrm{~mL})$ were added sequentially twice and mixed vigorously. To facilitate phase separation, $5 \mathrm{~mL}$ of saturated $\mathrm{NaCl}$ solution was added, and the mixture was mixed vigorously and left for phase separation. After separation, the bottom layer (fatty acids) was separated and removed from the top layer (sterols).

\subsection{GC-MS Analysis of Phytosterols}

Phytosterol portion was dried with $\mathrm{MgSO}_{4}$ and evaporated using a vacuum rotary evaporator to remove the extraction solvent. The resultant residue was added with $0.2 \mathrm{~mL}$ of pyridine and $0.2 \mathrm{~mL}$ of BSTFA (silylation agent) in a capped tube. Cholesterol (1.0 mg, Sigma-Aldrich, Steinheim, Germany) was added as the internal standard. The reaction was heated at $60{ }^{\circ} \mathrm{C}$ for $45 \mathrm{~min}$ in an incubator orbital shaker at $110 \mathrm{rpm}$. Once derivatization was completed, the mixture was transferred to small capped tubes and subjected to GC-MS analysis. Scanning was performed at an EI of $70 \mathrm{eV}$, at a mass range of $50-400 \mathrm{~m} / \mathrm{z}$, and with a 5 -scan s ${ }^{-1}$ mode. The carrier gas used was helium with a flow rate of

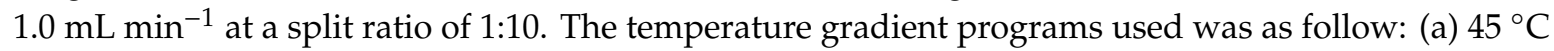
for $3 \mathrm{~min}$, (b) $45^{\circ} \mathrm{C}$ to $220^{\circ} \mathrm{C}$ at a rate of $5{ }^{\circ} \mathrm{C} \mathrm{min}^{-1}$, and (c) $220^{\circ} \mathrm{C}$ to $250{ }^{\circ} \mathrm{C}$ at a rate of $10{ }^{\circ} \mathrm{C}$ $\mathrm{min}^{-1}$ and, lastly, maintained at $250^{\circ} \mathrm{C}$ for $2 \mathrm{~min}$. The injector was held at a temperature of $260^{\circ} \mathrm{C}$. Identification of plant sterols was based on the comparison of experimentally obtained mass spectra with ones available in literature and with relative retention times of standards. The concentrations of identified phytosterols were obtained by comparing the peak area of each compound to the peak area of the internal standard, cholesterol, with a concentration of $1 \mathrm{mg} / \mathrm{mL}$.

\subsection{GC-MS Analysis of Fatty Acids}

The fatty acid portion was acidified with $1 \mathrm{M} \mathrm{HCl}$ and extracted with $10 \mathrm{~mL}$ of hexane. The organic portion was separated and subjected to a vacuum rotary evaporator to remove the extraction solvent. Next, the sample was subjected to methylation $\left(10 \mathrm{~min}, 80^{\circ} \mathrm{C}\right)$ by adding $4 \mathrm{~mL}$ of $14 \% \mathrm{BF}_{3} / \mathrm{MeOH}(v / v)$. Fatty acid methyl esters (FAMEs) that were formed were extracted using $2.5 \mathrm{~mL}$ of hexane, dried with $\mathrm{MgSO}_{4}$, and filtered using a cotton plug and silicate power into a small container. The FAME profile was analyzed using GC-MS (GCMS-QP 2020, Shimadzu, Kyoto, Japan). Separation was conducted using the Zebron ZB-WAX capillary column $(30 \mathrm{~m} \times 0.25 \mathrm{~mm}$ i.d. $\times 0.25 \mu \mathrm{m}$ film thickness) (Phenomenex, Torrance, CA, USA). GC-MS analysis was conducted as follows: Scanning was performed from $50-400 \mathrm{~m} / \mathrm{z}$ in electronic impact (EI) at $70 \mathrm{eV}$, in the 5 -scan s ${ }^{-1}$ mode. Helium was used as the carrier

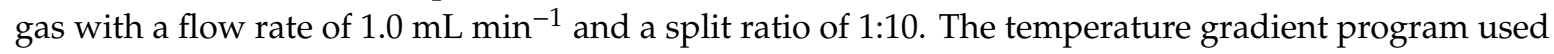
was (a) $45^{\circ} \mathrm{C}$ for $3 \mathrm{~min}$; (b) $45-220^{\circ} \mathrm{C}$ with a rate of $5^{\circ} \mathrm{C} \mathrm{min}^{-1}$; (c) $220-250{ }^{\circ} \mathrm{C}$ at a rate of $10^{\circ} \mathrm{C} \mathrm{min}-1$ and kept at $250{ }^{\circ} \mathrm{C}$ for $2 \mathrm{~min}$. An injector was held at $260^{\circ} \mathrm{C}$.

\subsection{Color Analysis}

The colors of fresh and dried powdered P. nodiflora leaves were determined with Minolta a Chroma Meter CR-200 (Minolta Co. Ltd., Osaka, Japan). Color data were expressed as CIE $L^{*}, a^{*}, b^{*}$ coordinates. Color measurements were measured five times to obtain a mean value per sample. 


\subsection{Water Activity Analysis}

The water activity of fresh and dried leaves was determined with a water-activity meter (Aqualab 4TE, Pullman, WA, USA). Fresh and ground leaves were placed and spread up to three-fourths of the sample cup which was inserted into the measuring chamber. Measurement of water activity was carried out at an average temperature of $24.9 \pm 0.05^{\circ} \mathrm{C}$.

\subsection{Statistical Analysis}

Results are presented as mean \pm standard deviation. One-way analysis of variance (ANOVA) was conducted using SPSS 20 (IBM, Tulsa, OK, USA). Significant differences between means were evaluated using Tukey's test at a significance level of $p \leq 0.05$. Mathematical modelling of the drying kinetics of CD, VMD, and CPD-VMFD methods was achieved with Table Curve 2D Windows v2.03 (Jandel Scientific Software, San Jose, CA, USA). $R^{2}$ RMSE were used to evaluate the goodness of fit of models (Equations (3)-(5)) to experimental data. All determinations were performed in triplicate.

\section{Conclusions}

The drying kinetics of $P$. nodiflora leaves were best described by the modified Page model. VMD achieved the shortest drying time, whereas CD was the most time-consuming method. However, the application of VMFD, in CPD-VMFD reduced drying time of CD considerably. The application of CPD-VMFD is also justified by the lower specific energy consumption compared with conventional CD. CPD-VMFD reduced the final specific energy consumptions by $80.2 \%$ and $51.1 \%$ (kJ/g water) compared with $\mathrm{CD} 50^{\circ} \mathrm{C}$. Moreover, $\mathrm{CPD}$ was effective in reducing water content by approximately $92.4 \%$, from the initial moisture content of 7.032 to $0.537 \mathrm{~kg}$ water $\mathrm{kg}^{-1} \mathrm{dw}$ of samples. Based on the antioxidant-activity results, VMD at $6 \mathrm{~W} / \mathrm{g}$ showed the highest antioxidant activity, consistent for both ABTS and FRAP analyses. $\beta$-Sitosterol was the major fatty acid that may have contributed to the antioxidant activity of P. nodiflora. Water-activity results showed that all methods produced samples that were microbiologically and shelf stable. Color analysis revealed that CPD-VMFD was superior in preserving the color of P. nodiflora. CPD-VMFD is a promising drying method based on the results of TPC, volatile, and phytosterol analysis.

Author Contributions: L.Y.W.C., B.L.C., C.H.C. and A.F. designed the experiment. L.Y.W.C., A.F., A.S., A.W. and J.Ł. performed the experiments. L.Y.W.C. (supported by B.L.C., A.F. and C.H.C.) wrote the manuscript.

Funding: The authors would like to acknowledge Taylor's University Lakeside for providing financial support under Taylor's Research Grant Schemes (TRGS/MFS/1/2017/SOE/008) and The Polish Ministry of Science and Higher Education "Strategy of Excellence-University of Research" Project (0019/SDU/2018/18).

Conflicts of Interest: The authors declare no conflict of interest.

\section{References}

1. Halliwell, B.; Aeschbach, R.; Löliger, J.; Aruoma, O.I. The characterization of antioxidants. Food Chem. Toxicol. 1995, 33, 601-617. [CrossRef]

2. Flora, G.; Mittal, M.; Flora, S.J.S. Medical countermeasures-chelation therapy. In Handbook of Arsenic Toxicology; Flora, S.J.S., Ed.; Academic Press: London, UK, 2015; pp. 589-626.

3. Angerhofer, C.K.; Maes, D.; Giacomoni, P.U. The Use of natural compounds and botanicals in the development of anti-aging skin care products. In Skin Aging Handbook; Dayan, N., Ed.; William Andrew: New York, NY, USA, 2009; pp. 205-263.

4. Sharma, R.A.; Singh, R. A review on Phyla nodiflora Linn.: A wild wetland medicinal herb. Int. J. Pharm. Sci. Rev. Res. 2013, 20, 57-63.

5. Salve, S.D.; Bhuktar, A.S. Pharmacognostic study of Phyla nodiflora Linn. Int. Res. J. Pharm. 2012, 3, $255-260$.

6. Ashokkumar, D.; Thamilselvan, V.; Senthilkumar, G.P.; Mazumder, U.K.; Gupta, M. Antioxidant and free radical scavenging effects of Lippia nodiflora. Pharm. Biol. 2008, 46, 762-771. [CrossRef] 
7. Sudha, A.; Srinivasan, P. Bioassay-guided isolation and antioxidant evaluation of flavonoid compound from aerial parts of Lippia nodiflora L. BioMed Res. Int. 2014, 2014, 549836. [CrossRef]

8. Chan, J.W.R.; Chong, C.H.; Ng, D.K.S. Process synthesis and design for extraction of bioactive compounds from Strobilanthes crispus. J. Eng. Sci. Technol. 2015, 113-137.

9. Sarker, S.D.; Latif, Z.; Gray, A.I. Natural product isolation. In Natural Products Isolation, 2nd ed.; Sarker, S.D., Satya, D., Eds.; Humana Press: Totowa, NJ, USA, 2005; pp. 1-25.

10. Chen, X.D.; Mujumdar, A.S. Drying Technologies in Food Processing; Blackwell Publihing: Oxford, UK, 2008; pp. 1-52.

11. Wray, D.; Ramaswamy, H.S. Novel concepts in microwave drying of foods. Dry. Technol. 2015, 33, 769-783. [CrossRef]

12. Wojdyło, A.; Figiel, A.; Lech, K.; Nowicka, P.; Oszmiański, J. Effect of convective and vacuum-microwave drying on the bioactive compounds, color, and antioxidant capacity of sour cherries. Food Bioprocess Technol. 2014, 7, 829-841. [CrossRef]

13. Calín-Sánchez, Á.; Lech, K.; Szumny, A.; Figiel, A.; Carbonell-Barrachina, Á.A. Volatile composition of sweet basil essential oil (Ocimum basilicum L.) as affected by drying method. Food Res. Int. 2012, 48, 217-225. [CrossRef]

14. Figiel, A. Drying kinetics and quality of beetroots dehydrated by combination of convective and vacuum-microwave methods. J. Food Eng. 2010, 98, 461-470. [CrossRef]

15. Drouzas, A.E.; Schubert, H. Microwave application in vacuum drying of fruits. J. Food Eng. 1996, 28, $203-209$. [CrossRef]

16. Hu, Q.G.; Zhang, M.; Mujumdar, A.S.; Xiao, G.N.; Sun, J.-C. Drying of edamames by hot air and vacuum microwave combination. J. Food Eng. 2006, 77, 977-982. [CrossRef]

17. Calín-Sánchez, Á.; Figiel, A.; Lech, K.; Szumny, A.; Carbonell-Barrachina, Á.A. Effects of drying methods on the composition of thyme (Thymus vulgaris L.) essential oil. Dry. Technol. 2013, 31, 224-235. [CrossRef]

18. Figiel, A.; Szumny, A.; Gutiérrez-Ortíz, A.; Carbonell-Barrachina, Á.A. Composition of oregano essential oil (Origanum vulgare) as affected by drying method. J. Food Eng. 2010, 98, 240-247. [CrossRef]

19. Chua, K.J.; Chou, S.K. Recent advances in hybrid drying technologies. In Emerging Technologies for Food Processing, 2nd ed.; Sun, D.W., Ed.; Academic Press: London, UK, 2014; pp. 447-457.

20. Scaman, C.H.; Durance, T.D. Combined microwave vacuuum-drying. In Emerging Technologies for Food Processing, 2nd ed.; Sun, D.W., Ed.; Academic Press: London, UK, 2014; pp. 507-533.

21. Calín-Sanchez, Á.; Figiel, A.; Szarycz, M.; Lech, K.; Nuncio-Jáuregui, N.; Carbonell-Barrachina, Á.A. Drying kinetics and energy consumption in the dehydration of pomegranate (Punica granatum L.) arils and rind. Food Bioprocess Technol. 2014, 7, 2071-2083. [CrossRef]

22. Soysal, Y.; Öztekin, S.; Eren, Ö. Microwave rrying of parsley: Modelling, kinetics, and energy aspects. Biosyst. Eng. 2006, 93, 403-413. [CrossRef]

23. Chong, K.L.; Lim, Y.Y. Effects of drying on the antioxidant properties of herbal tea from selected vitex species. J. Food Qual. 2012, 35, 51-59. [CrossRef]

24. Yi, W.; Wetzstein, H.Y. Effects of drying and extraction conditions on the biochemical activity of selected herbs. HortScience 2011, 46, 70-73. [CrossRef]

25. Hossain, M.B.; Barry-Ryan, C.; Martin-Diana, A.B.; Brunton, N.P. Effect of drying method on the antioxidant capacity of six Lamiaceae herbs. Food Chem. 2010, 123, 85-91. [CrossRef]

26. Wojdyło, A.; Figiel, A.; Oszmiański, J. Effect of drying methods with the application of vacuum microwaves on the bioactive compounds, color, and antioxidant activity of strawberry fruits. J. Agric. Food Chem. 2009, 57, 1337-1343. [CrossRef]

27. Yahia, E.M. The contribution of fruit and vegetable consumption to human health. In Fruit and Vegetable Phytochemicals; John Wiley \& Sons: Hoboken, NJ, USA, 2009; pp. 3-51.

28. Gonzalez, M.E.; Barrett, D.M. Thermal, high pressure, and electric field processing effects on plant cell membrane integrity and relevance to fruit and vegetable quality. J. Food Sci. 2010, 75, 121-130. [CrossRef]

29. Abdullah, S.; Shaari, A.R.; Azimi, A. Effect of drying methods on metabolites composition of misai kucing (Orthosiphon stamineus) leaves. APCBEE Procedia 2012, 2, 178-182. [CrossRef]

30. Rabeta, M.S.; Lai, S.Y. Effects of drying, fermented and unfermented tea of Ocimum tenuiflorum linn. on the antioxidant capacity. Int. Food Res. J. 2013, 20, 1601-1608.

31. Dixon, R.A.; Harrison, M.J.; Paiva, N.L. The isoflavonoid phytoalexin pathway: From enzymes to genes to transcription factors. Physiol. Plant. 1995, 93, 385-392. [CrossRef] 
32. Walton, N.J.; Brown, D.E.; Harborne, J.B. Classes and functions of secondary products from plants. In Chemicals from Plants; Alvarez, M.A., Ed.; Imperial College Press: London, UK, 2011; pp. 1-25.

33. Ludwiczuk, A.; Skalicka-Woźniak, K.; Georgiev, M.I. Terpenoids. In Pharmacognosy: Fundamentals, Applications and Strategy; Badal, S., Delgoda, R., Eds.; Academic Press: London, UK, 2016; pp. 233-265.

34. Lee, K.G.; Shibamoto, T. Antioxidant properties of aroma compounds isolated from soybeans and mung beans. J. Agric. Food Chem. 2000, 48, 4290-4293. [CrossRef]

35. Szumny, A.; Figiel, A.; Gutiérrez-Ortíz, A.; Carbonell-Barrachina, Á.A. Composition of rosemary essential oil (Rosmarinus officinalis) as affected by drying method. J. Food Eng. 2010, 97, 253-260. [CrossRef]

36. Buchaillot, A.; Caffin, N.; Bhandari, B. Drying of lemon myrtle (Backhousia citriodora) leaves: Retention of volatiles and color. Dry. Technol. 2009, 27, 445-450. [CrossRef]

37. Dong, W.; Cheng, K.; Hu, R.; Chu, Z.; Zhao, J.; Long, Y. Effect of microwave vacuum drying on the drying characteristics, color, microstructure, and antioxidant activity of green coffee beans. Molecules 2018, 23, 1146. [CrossRef]

38. Therdthai, N.; Zhou, W. Characterization of microwave vacuum drying and hot air drying of mint leaves (Mentha cordifolia Opiz ex Fresen). J. Food Eng. 2009, 91, 482-489. [CrossRef]

39. Lampi, A.M.; Juntunen, L.; Toivo, J.; Piironen, V. Determination of thermo-oxidation products of plant sterols. J. Chromatogr. B Anal. Technol. Biomed. Life Sci. 2002, 777, 83-92. [CrossRef]

40. Soupas, L.; Juntunen, L.; Lampi, A.M.; Piironen, V. Effects of sterol structure, temperature, and lipid medium on phytosterol oxidation. J. Agric. Food Chem. 2004, 52, 6485-6491. [CrossRef]

41. Rudzińska, M.; Przybylski, R.; Wąsowicz, E. Products formed during thermo-oxidative degradation of phytosterols. JAOCS J. Am. Oil Chem. Soc. 2009, 86, 651-662. [CrossRef]

42. Adams, R.P. Identification of Essential Oil Components by Gas Chromatography/Mass Spectrometry; Allured publishing Corporation: Carol Stream, IL, USA, 2007; pp. 1-804.

43. Shin, H.Y.; Lim, S.M.; Bae, S.Y.; Oh, S.C. Thermal decomposition and stability of fatty acid methyl esters in supercritical methanol. J. Anal. Appl. Pyrolysis 2011, 92, 332-338. [CrossRef]

44. Charuwat, P.; Boardman, G.; Bott, C.; Novak, J.T. Thermal degradation of long chain fatty acids. Water Environ. Res. 2018, 90, 278-287. [CrossRef]

45. National Center for Biotechnology Information. Available online: https://pubchem.ncbi.nlm.nih.gov/ compound/985 (accessed on 3 September 2018).

46. National Center for Biotechnology Information. Available online: https://pubchem.ncbi.nlm.nih.gov/ compound/5280934 (accessed on 3 September 2018).

47. Bourourou, M.; Duncan, M.W.; Lipsky, R.H.; Gorelick, P.B.; Marini, A.M.; Blondeau, N. Alpha-linolenic acid: An omega-3 fatty acid with neuroprotective properties-Ready for use in the stroke clinic? BioMed Res. Int. 2015, 2015, 519830 .

48. Sledz, M.; Witrowa-Rajchert, D. Influence of microwave-convective drying of chlorophyll content and color of herbs. Acta Agrophys. 2012, 19, 865-876.

49. Fratianni, A.; Niro, S.; Alam, M.D.R.; Cinquanta, L.; Di Matteo, M.; Adiletta, G.; Panfili, G. Effect of a physical pre-treatment and drying on carotenoids of goji berries (Lycium barbarum L.). LWT Food Sci. Technol. 2018, 92, 318-323. [CrossRef]

50. Boon, C.S.; McClements, D.J.; Weiss, J.; Decker, E.A. Factors influencing the chemical stability of carotenoids in foods. Crit. Rev. Food Sci. Nutr. 2010, 50, 515-532. [CrossRef]

51. Samoticha, J.; Wojdyło, A.; Lech, K. The influence of different the drying methods on chemical composition and antioxidant activity in chokeberries. LWT Food Sci. Technol. 2016, 66, 484-489. [CrossRef]

52. Schmidt, S.J.; Fontana, A.J. Appendix E: Water activity values of select food ingredients and products. In Water Activity in Foods: Fundamentals and Applications; Barbosa-Canovas, G.V., Fontana, A.J., Schmidt, S.J., Labuza, T.P., Eds.; Blackwell Publishings: Ames, IA, USA, 2008; pp. 407-420.

53. Calín-Sánchez, Á.; Figiel, A.; Wojdyło, A.; Szarycz, M.; Carbonell-Barrachina, Á.A. Drying of garlic slices using convective pre-drying and vacuum-microwave finishing drying: Kinetics, energy consumption, and quality studies. Food Bioprocess Technol. 2014, 7, 398-408. [CrossRef]

54. Re, R.; Pellegrini, N.; Proteggente, A.; Pannala, A.; Yang, M.; Rice-Evans, C. Antioxidant activity applying an improved ABTS radical cation decolorization assay. Free Rad. Biol. Med. 1999, 26, 1231-1237. [CrossRef]

55. Benzie, I.F.F.; Strain, J.J. The ferric reducing ability of plasma (FRAP) as a measure of "antioxidant power": The FRAP assay. Anal. Biochem. 1996, 239, 70-76. [CrossRef] 
56. Gao, X.; Ohlander, M.; Jeppsson, N.; Björk, L.; Trajkovski, V. Changes in antioxidant effects and their relationship to phytonutrients in fruits of sea buckthorn (Hippophae rhamnoides L.) during maturation. J. Agric. Food Chem. 2000, 48, 1485-1490. [CrossRef]

57. Folch, J.; Lees, M.; Stanley, G.H.S. A simple method for the isolation and purification of total lipids from animal animal tissues. J. Biol. Chem. 1957, 226, 497-509.

(C) 2019 by the authors. Licensee MDPI, Basel, Switzerland. This article is an open access article distributed under the terms and conditions of the Creative Commons Attribution (CC BY) license (http://creativecommons.org/licenses/by/4.0/). 